\title{
Perspective
}

\section{A Review and Update of Mechanisms of Estrogen in the Hippocampus and Amygdala for Anxiety and Depression Behavior}

\author{
Alicia A Walf' and Cheryl A Frye $\mathbf{e}^{*, 1,2,3,4}$ \\ 'Department of Psychology, The University at Albany-SUNY, Albany, NY, USA; ${ }^{2}$ Department of Biological Sciences, The University at Albany- \\ SUNY, Albany, NY, USA; ${ }^{3}$ Center for Neuroscience Research, The University at Albany-SUNY, Albany, NY, USA; ${ }^{4}$ Center for Life Science Research, \\ The University at Albany-SUNY, Albany, NY, USA
}

\begin{abstract}
Estrogen $\left(E_{2}\right)$ has many effects in the central nervous system, including effects on anxiety and depression behavior. This review will address effects of $E_{2}$ on behaviors related to anxiety and depression in women and animal models and include recent findings from our laboratory related to this topic. $E_{2}$ 's antianxiety and antidepressant-like effects may depend upon many factors, including the regimen of $E_{2}$ utilized and interactions with the hypothalamic-pituitary-adrenal axis. Brain targets for $E_{2}$ 's effects on anxiety and depression include the hippocampus and amygdala. Administration of $E_{2}$, compared to vehicle, subcutaneously or to the hippocampus or amygdala of ovariectomized rats decreases anxiety and depressive behavior. Intracellular estrogen receptors (ERs) may be important for $E_{2}$ 's anxiolytic and antidepressant-like effects. Administration of an ER antagonist to the hippocampus, but not amygdala, increases anxiety and depression behavior of naturally receptive female rats. Studies utilizing ER knockout mice or selective ER modulators suggest that ER-mediated effects of $E_{2}$ on anxiety and depressive behavior may require $E R \beta$. In addition, the behavioral effects of $E_{2}$ may involve membrane actions and/or changes in cell cycle processes involved in energy expenditure. Elucidating the mechanisms by which $E_{2}$ affects anxiety and depression is important in order to enhance its therapeutic potential. It is particularly important to investigate the putative receptor mechanisms and brain targets for $E_{2}$ to determine whether mood-enhancing effects of $E_{2}$ can occur without deleterious proliferative effects in reproductive tissues.
\end{abstract}

Neuropsychopharmacology (2006) 3 I, 1097-IIII. doi: I0.1038/sj.npp. I30 I067; published online 22 March 2006

Keywords: sex differences; affect; mood; estrogen receptor; SERMs; hippocampus; amygdala

\section{INTRODUCTION}

Estrogen $\left(\mathrm{E}_{2}\right)$ has a wide range of effects in body and brain, and its therapeutic potential for mood, among other physiological and psychological processes, has been recognized for some time. Indeed, one of the initial investigations of how mood may be improved by $\mathrm{E}_{2}$ was published over 100 years ago and details 36 case studies of women who had various neuropsychological conditions and were administered ovarian extracts (Easterbrook, 1900). Despite such a history of interest in this topic, many questions remain about the effects, brain targets, and mechanisms of $E_{2}$ for its effects on mood/affect. This is a clinically relevant question.

*Correspondence: Dr CA Frye, Department of Psychology, The University at Albany-SUNY, Life Sciences Research Building 01058, | 400 Washington Avenue, Albany, NY 12222, USA, Tel: + | 51859 | 8839, Fax: + | 518 59| 8848, E-mail: cafrye@albany.edu

Received 13 September 2005; revised 25 January 2006; accepted 9 February 2006

Online publication: 17 February 2006 at http://www.acnp.org/citations/ Npp021706050570/default.pdf
People are living longer (especially women), and age of menopause has remained stable, such that many women will be postmenopausal, with low or declining $\mathrm{E}_{2}$ levels, for nearly half their lives. Recent controversies on the clinical utility of $\mathrm{E}_{2}$-based hormone therapies further justify the need to investigate $E_{2}$ 's effects, mechanisms, and brain targets (Brunner et al, 2005; Hays et al, 2003; Rapp et al, 2003; Rossouw et al, 2002; Shumaker et al, 2003; Smoller et al, 2003). Studies investigating $\mathrm{E}_{2}$ 's effects on mood in women and limitations to these approaches will be discussed. Given that animal models may provide a means to address these limitations and characterize $\mathrm{E}_{2}$ 's effects and actions, this literature will also be reviewed and recent findings from our laboratory will be discussed.

\section{Overview of Clinical Findings of $E_{2}$ 's Effects to Alter Anxiety and Depression Among Women}

Gender differences. Women may be more vulnerable than men to develop anxiety or depression disorders. There is a greater incidence of most types of anxiety disorders 
(ie social anxiety, phobias, post-traumatic stress disorder, general anxiety disorder) among women compared to men (Breslau et al, 1995; Kessler et al, 1994; Schneier et al, 1992; Seeman, 1997). Women are twice as likely to experience major depression, particularly unipolar depression, compared to men (Earls, 1987; Kessler et al, 1993; Nolen-Hoeksema, 1987). Among people with depression, depressive episodes are more protracted and recur more frequently in women than in men (Earls, 1987; NolenHoeksema, 1987). Women's increased vulnerability to these mood disorders are especially apparent in major depression with comorbid anxiety disorders (Breslau et al, 1995). Given that anxiety may be accompanied by symptoms of depression and be a precursor for development of depression (Paul, 1988), it is important to consider both anxiety and depression when investigating factors, such as $E_{2}$, that may alter mood (reviewed by Seeman, 1997; Young, 1998; Young and Korszun, 2002). Women's increased vulnerability to mood disorders occurs postpubertally, with the beginning of cyclical changes in $\mathrm{E}_{2}$ secretion from the ovaries (reviewed by Hayward and Sanborn, 2002; Kessler and Walters, 1998; Lewinsohn et al, 1998). Plasma $\mathrm{E}_{2}$ levels are significantly lower among depressed women (Young et al, 2000). Thus, $\mathrm{E}_{2}$ may precipitate the increased incidence and/or symptomology of mood disorders in women.

Effects of endogenous changes in $E_{2}$ levels. Changes in endogenous $\mathrm{E}_{2}$ levels may increase women's susceptibility to anxiety and depression disorders. Women are uniquely at risk for mood disorders, such as premenstrual dysphoric disorder and postpartum depression, that typically occur concurrent with changes in endogenous $\mathrm{E}_{2}$ levels (Bebbington et al, 1981; reviewed by Bloch et al, 2003; Jenkins, 1987; reviewed by Rubinow and Schmidt, 1995; Weissman and Klerman, 1977). In one study, nearly half of the women admitted to psychiatric hospitals for a variety of symptoms were admitted immediately before or during menstruation, and the incidence of suicide was greater at these times (Dalton, 1959). Some, but not all, studies report higher suicide incidence among women during the luteal, compared to follicular, phase (as reviewed by Baca-Garcia et al, 2000). Furthermore, symptoms of postpartum depression typically occur within the 1st week after parturition when $\mathrm{E}_{2}$ levels precipitously decline from the high levels during pregnancy (Dean and Kendell, 1981). Although these data suggest that changes in $\mathrm{E}_{2}$ levels may underlie the increased susceptibility of women to develop affective disorders, these changes occur concomitant with alterations in levels of progesterone, androgens, and their metabolites, which may also alter mood (Roca et al, 2003). As such, it is important to consider the effects of $\mathrm{E}_{2}$ administration to women with low $\mathrm{E}_{2}$ levels to establish the role of $\mathrm{E}_{2}$ on mood.

Effects of $E_{2}$ levels on mood with aging. Dramatic changes in $E_{2}$ levels, as occur with surgical and/or natural menopause, are associated with changes in incidence and symptomology of anxiety and depression. During perimenopause, there are alterations in ovarian function, such that $\mathrm{E}_{2}$ levels can be variable (Burger et al, 1995; Daly et al, 2003; Santoro et al, 1996). This is followed by the postmenopausal period when $\mathrm{E}_{2}$ levels are declining or at nadir. In one longitudinal study, 29 asymptomatic, regularly cycling, premenopausal women were monitored for an average of 5 years until they were amenorrheic for 6 or more months (Schmidt et al, 2004). There were 11 episodes of new-onset depression, as determined by subjective mood ratings and the Structured Clinical Interview for DSM-IV, in nine of the 29 women. Furthermore, during the late perimenopause period in these women (ie 24 months surrounding their last menstruation), the majority of the episodes (nine) of depression occurred. These data suggest that incidence of depression among some women may be increased during late perimenopause. Incidence of anxiety and depression disorders increases postmenopausally. Generalized anxiety disorder occurs in $\sim 5 \%$ of the population, but the incidence doubles among older, postmenopausal women (Bebbington et al, 1981; Jenkins, 1987; Weissman and Klerman, 1977; Wittchen and Hoyer, 2001). Incidence of bipolar and major depression are increased among postmenopausal women (Bebbington et al, 1998; reviewed by Goodwin and Jamison, 1990; Weissman and Olfson, 1995). In a cross-sectional study of older postmenopausal women, Beck Depression Inventory scores were inversely related to plasma $\mathrm{E}_{2}$ levels. Those in the lower-half of the distribution had higher scores than those in the top-half (Almeida et al, 2005).

$\mathrm{E}_{2}$ replacement to nondepressed, naturally- or surgically menopausal women can improve mood scores, although not all studies find such improvement (Ditkoff et al, 1991; Heinrich and Wolf, 2005; Miller et al, 2002; Morrison et al, 2004; Rausch and Parry, 1993; Sherwin, 1991; Sherwin and Gelfand, 1985). Recent double-blind, placebo-controlled studies of perimenopausal women with depression demonstrated that $\mathrm{E}_{2}$ therapy may provide some mood benefits among older women (Cohen et al, 2003; Schmidt et al, 2000; Soares et al, 2001). Higher scores on the Geriatric Depression Scale (ie greater depressive symptoms) were found among older, postmenopausal women diagnosed with Alzheimer's Disease, particularly among those who were not on $\mathrm{E}_{2}$ therapy, compared to healthy controls (Carlson et al, 2000). Thus, low endogenous $\mathrm{E}_{2}$ levels with aging may be associated with anxiety and/or depression disorders, and $\mathrm{E}_{2}$ may counter some of these effects.

Effects of $E_{2}$ administration to women with low $E_{2}$ levels. $\mathrm{E}_{2}$ administration to young women with low $\mathrm{E}_{2}$ levels may alter mood. Transdermal $\mathrm{E}_{2}$ decreased self-reported negative mood in women with severe premenstrual syndrome (Smith et al, 1995). In women with postpartum depression, administration of sublingual or transdermal $E_{2}$ sufficiently improves depressive symptoms to meet the definition of clinical recovery (Ahokas et al, 2001; Gregoire et al, 1996). Young, adult women diagnosed with major depressive disorder given $\mathrm{E}_{2}$ treatment had improved affect (Klaiber et al, 1979). These data suggest that $E_{2}$ can have beneficial effects among women with intact neuroendocrine feedback. Additionally, there are similar effects of $E_{2}$ administration to improve mood among women with low $\mathrm{E}_{2}$ levels. In support, $\mathrm{E}_{2}$, alone or in combination with the selective serotonin reuptake inhibitor, fluvoxamine, significantly decreased self-rated depression scores among oophorectomized women with depressive symptoms (Nagata et al, 2005). Furthermore, among women without pre-existing 
neuropsychiatric conditions, gonadotropin-releasing hormone agonists, which decrease $\mathrm{E}_{2}$ levels, increase depressive mood symptoms (as reviewed by Warnock et al, 2000). However, a different pattern of effects is observed in women that have been diagnosed with mood disorders, as discussed in detail below.

Limitations to investigating $E_{2}$ 's effects on mood of women. The data discussed above focus on the beneficial effects of $\mathrm{E}_{2}$ administration to individuals with low and/or absent $\mathrm{E}_{2}$ levels; however, not all individuals respond favorably to $E_{2}$. Among women, psychiatric history and current and prior $E_{2}$ exposure (eg length of time in an $\mathrm{E}_{2}$-deficient, postmenopausal state before initiation of $\mathrm{E}_{2}$ therapy) may alter the responses to $\mathrm{E}_{2}$ (Klaiber et al, 1997). Some women with anxiety disorders report less anxiety when $\mathrm{E}_{2}$ levels are low and/or stable (Schmidt et al, 1998), rather than rising, suggesting that some individuals may be more sensitive to $\mathrm{E}_{2}$ than are others. Indeed, women with postpartum depression or premenstrual syndrome respond favorably to gonadotropin-releasing hormone agonists, which stabilize $\mathrm{E}_{2}$ levels, unlike women without these disorders (Bloch et al, 2000; Schmidt et al, 1998). Furthermore, in two double-blind, placebo-controlled studies of $E_{2}$ replacement, baseline $E_{2}$ levels or those produced by $\mathrm{E}_{2}$ therapy did not predict a favorable response to $\mathrm{E}_{2}$ for mood scores, despite women having similar diagnoses and meeting endocrine criteria for perimenopause (Schmidt et al, 2000; Soares et al, 2001). In an in-patient study of severely depressed pre- and postmenopausal women, oral conjugated $\mathrm{E}_{2}$ therapy, compared to placebo, improved ratings on the Hamilton Scale of Depression; however, the response to $\mathrm{E}_{2}$ varied as a function of depression duration, such that women with a shorter history of depression had a better response to $E_{2}$ than those with a longer history of depression (Klaiber et al, 1979). Other reports have demonstrated that the $\mathrm{E}_{2}$ regimen utilized contributes to its efficacy (Gregoire et al, 1996; Saletu et al, 1995). Negligible findings for beneficial effects of $\mathrm{E}_{2}$ on mood of older, postmenopausal women in the Women's Health Initiative studies further support the idea that response to $\mathrm{E}_{2}$ may be sensitive to individual differences among women (ie differences in exposure to $\mathrm{E}_{2}$ and length of time without such exposure, psychiatric history, etc) and the regimen of $\mathrm{E}_{2}$ utilized (Brunner et al, 2005; Hays et al, 2003; Smoller et al, 2003). Moreover, $\mathrm{E}_{2}$ levels are lower among women with depression, suggesting that neuropsychiatric diagnoses may influence endocrine function (Young et al, 2000). As it is essential to control and/or evaluate these factors to elucidate role of $E_{2}$, it may be more beneficial to use animal models.

\section{Overview of Supporting Data from Animal Models for $\mathrm{E}_{2}$ 's Effects on Anxiety and Depression Behavior}

Sex differences. There are sex differences in anxiety and depression behavior of adult rodents that may depend, in part, upon $\mathrm{E}_{2}$ levels (as reviewed by Palanza, 2001). Female rodents have increased anxiety behavior compared to males in some tasks and, when estrous cycle is not considered, opposite effects can be seen (Blanchard et al, 1992; as reviewed by Blanchard et al, 1991; Johnston and File, 1991;
Zimmerberg and Farley, 1993). The magnitude of the sex difference may depend upon the motor demands of the task, given that $\mathrm{E}_{2}$ increases motor activity of female rodents (Becker et al, 1987; Frye et al, 2000; Morgan and Pfaff, 2001, 2002). Indeed, sex differences in affective behavior of rodents are more evident when endogenous changes in $\mathrm{E}_{2}$ levels during the estrous cycle are considered.

Estrous cycle changes. Changes in endogenous levels of $\mathrm{E}_{2}$ can alter anxiety and depressive behavior of rodents. Rodents show decreased anxiety and depression behavior during the late proestrous phase of the estrous cycle (ie behavioral estrus), when $\mathrm{E}_{2}$ levels are high and sexually receptive behavior is displayed. Naturally receptive rats have increased open arm time in the plus maze, increased time spent in the center of a brightly lit open field, decreased latencies to emerge from a dark chamber, increased time spent in social interaction with a conspecific, decreased freezing in response to footshock, and increased immobility in the forced swim test, compared to rats with lower endogenous $\mathrm{E}_{2}$ levels (ie nonreceptive rats in diestrus or male conspecifics; Contreras et al, 2000; Diaz-Veliz et al, 1997; Frye et al, 2000; Frye and Walf, 2002; Frye and Wawrzycki, 2003; Marcondes et al, 2001; Marvan et al, 1996, 1997; Mora et al, 1996). Additionally, pregnancy in rats is associated with persistently high $\mathrm{E}_{2}$ levels and decreased anxiety and depression behavior (Frye and Walf, 2004b; Zuluaga et al, 2005). Although these data support a role of natural variations in $\mathrm{E}_{2}$ concentrations to alter anxiety and depression behavior of rodents, these variations occur concomitant with fluctuations in progestins and androgens. Progestins and androgens also alter affective behaviors of female rodents (Frye et al, 2000, 2004; Frye and Lacey, 2001; Frye and Walf, 2002, 2004a, b; Rhodes and Frye, 2001; Walf et al, 2005). As such, it is important to determine whether $\mathrm{E}_{2}$ administration to rodents with low $\mathrm{E}_{2}$ levels is sufficient to increase antianxiety and antidepressant-like behavior.

Effects of age-related decline in endogenous $E_{2}$. Aged rodents provide a useful, but less studied, model to investigate the effects of decline in endogenous $E_{2}$ source for anxiety and depression behavior. Female mice with lifelong low levels of $\mathrm{E}_{2}$ due to deletion of the follitropin receptor have increased anxiety behavior at ages typically associated with decline in ovarian function among wild-type mice ( + 20 months old; Danilovich et al, 2003). We have demonstrated that intact aged female mice have very low central $\mathrm{E}_{2}$ levels (Frye et al, 2005), which can be increased with administration of $10 \mu \mathrm{g} \mathrm{E}_{2}$ systemically. We have begun to look at the effects of $\mathrm{E}_{2}$ administration on anxiety and depression behaviors in aging by using intact female mice that are 24-28 months old. At $1 \mathrm{~h}$ before testing in several tasks of affective behavior, mice were administered $\mathrm{E}_{2}$ $(10 \mu \mathrm{g})$ or vehicle (sesame oil) and then received a second injection of the selective estrogen receptor (ER) modulator (SERM), raloxifene $(3 \mathrm{mg} / \mathrm{kg})$, or vehicle. Compared to vehicle, $\mathrm{E}_{2}$ and/or raloxifene to aged mice decreases anxiety and depression behavior across several tasks (see Table 1). Together, these data suggest that decline in $\mathrm{E}_{2}$ with aging is associated with increased anxiety behavior, and aged rodents can respond favorably to $\mathrm{E}_{2}$ or SERMs. 
Table I Affective Behavior (Mean \pm SEM) of Aged Female Mice Administered $E_{2}$ and/or Raloxifene

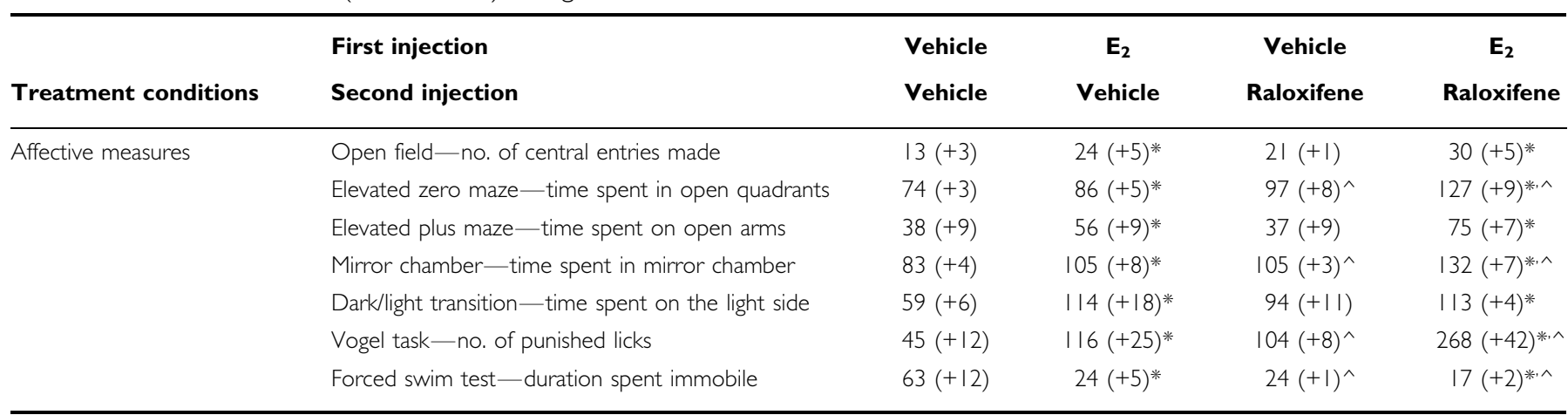

Significant difference between $\mathrm{E}_{2}$ and vehicle condition $(*)$, or raloxifene and vehicle $\left({ }^{\wedge}\right), p<0.05$.

Effects of extirpation and $E_{2}$ administration. Ovariectomy (ovx), removal of the primary source of $E_{2}$, the ovaries, is utilized as a model of $E_{2}$ deprivation to assess $E_{2}$ 's behavioral effects. Ovx increases anxiety and depression behavior and subcutaneous administration of $E_{2}$ can reverse these effects in several tasks (Bernardi et al, 1989; Bowman et al, 2002; Diaz-Veliz et al, 1997; Estrada-Camarena et al, 2003; Frye and Walf, 2004a; Frye and Wawrzycki, 2003; Hilakivi-Clarke, 1996; Luine et al, 1998; Marcondes et al, 2001; McCarthy et al, 1995, 1996; Mora et al, 1996; Nomikos and Spyraki, 1988; Okada et al, 1997; Rachman et al, 1998; Slater and Blizard, 1976; Walf and Frye, 2005a, b; Walf et al, 2004). Furthermore, in an animal model of postpartum decline in $E_{2}$, withdrawal from chronically sustained $E_{2}$ levels in ovx rats increases depressive behavior (Galea et al, 2001). Together, these data suggest that $E_{2}$ can increase antianxiety and antidepressant-like behavior. However, as in women, there is evidence for experience-, dose-, and/or duration-dependent effects of $\mathrm{E}_{2}$ on anxiety and depression behavior.

Experience and regimen-dependent effects of estrogen in animal models. The length of $\mathrm{E}_{2}$ exposure and/or decline may alter responses to subsequent $\mathrm{E}_{2}$ exposure. Studies investigating the effects of parity suggest that frequent exposure to chronic $\mathrm{E}_{2}$ can alter affective behavior of rodents. In support, exploration in the open field is lower among female rats that have never experienced high $\mathrm{E}_{2}$ levels during pregnancy compared to those that have repeatedly experienced this (Wartella et al, 2003). Thus, some differences observed among rodents for their response to $\mathrm{E}_{2}$ may be due to prior $\mathrm{E}_{2}$ experience.

$\mathrm{E}_{2}$ 's effects on anxiety and/or depression behavior of female rodents may depend upon the $\mathrm{E}_{2}$ concentration and/ or dosing utilized. Rats that are administered an $\mathrm{E}_{2}$ regimen that produces physiological $\mathrm{E}_{2}$ levels (similar to that observed in naturally receptive rats) have decreased anxiety and depression behavior (Estrada-Camarena et al, 2003; Frye and Walf, 2004a; Frye and Wawrzycki, 2003; Nomikos and Spyraki, 1988; Rachman et al, 1998; Slater and Blizard, 1976; Walf and Frye, 2005a, b). In contrast, very low or high dosages of $E_{2}$, or regimen that would not be expected to significantly increase circulating $\mathrm{E}_{2}$ concentrations at test time to levels observed in naturally receptive rats, generally show little or no decreases in anxiety and depression behavior (Diaz-Veliz et al, 1997, 2000; Estrada-Camarena et al, 2003; Martinez-Mota et al, 2000; Mora et al, 1996; Stoffel and Craft, 2004; Walf and Frye, 2005a). These data suggest that an $\mathrm{E}_{2}$ regimen that produces concentrations of $\mathrm{E}_{2}$ that are similar to that of naturally receptive rats decreases anxiety and depression behavior of ovx rodents.

In addition, the duration of $\mathrm{E}_{2}$ exposure may alter responses of ovx rodents. Activity in the open field is increased in ovx rats administered $\mathrm{E}_{2}$ for 5 , but not 35 days, via silastic capsules (Luine et al, 1998). Subchronic (3-7 days) administration of $\mathrm{E}_{2}$ that produces physiological $\mathrm{E}_{2}$ levels, but not higher dosages, decreases anxiety behavior (Koss et al, 2004; McCarthy et al, 1995; Morgan and Pfaff, 2001, 2002; Nomikos and Spyraki, 1988; Rodriguez-Sierra et al, 1984). Similarly, chronic administration of $\mathrm{E}_{2}$, which likely produces prolonged supraphysiological or physiological plasma $\mathrm{E}_{2}$ levels, increases depressive behavior of ovx rats and mice (Galea et al, 2002; Okada et al, 1997). In another model, $10 \mu \mathrm{g} \mathrm{E}_{2}$ for 1 week or $2 \mu \mathrm{g} \mathrm{E}_{2}$ for 2 weeks, but neither higher dosages nor longer treatment, increased choline acetyltransferase immunoreactivity in the basal forebrain (Gibbs, 1997). Using the defensive burial task, in which the duration rats spend burying an electrified prod with shavings following footshock is considered an index of anxiety behavior, we have examined the effects of $E_{2}$ regimen and length of exposure. We found that physiological $E_{2}$ regimen to ovx rats $\left(10 \mu \mathrm{g} E_{2}\right.$ for 2 days; $\left.42 \pm 24 \mathrm{~s}\right)$ decreased the duration spent burying an electrified prod, but behavior was not altered by neither very low $(2 \mu \mathrm{g}$ systemic injections $=322 \pm 36 \mathrm{~s}$ ) nor very high (silastic implants filled with $\left.\mathrm{E}_{2}=250 \pm 80 \mathrm{~s}\right) \quad \mathrm{E}_{2}$ concentrations present for 2 days prior to testing, as compared to vehicle administration $(203 \pm 41 \mathrm{~s})$. If silastic implants with $\mathrm{E}_{2}$ remained in place for 4 weeks, ovx rats demonstrated a modest decrease in time spent burying $(168 \pm 24 \mathrm{~s})$. These data suggest that both $\mathrm{E}_{2}$ concentration and length of exposure may influence $\mathrm{E}_{2}$ 's functional effects. Another factor that may alter $E_{2}$ 's effects on anxiety and depression behavior is the activity of the hypothalamic-pituitaryadrenal axis (HPA).

The role of the HPA axis in modifying the response to $E_{2}$. Sex- or hormone-related disparities in anxiety and depression disorders, and individual differences in response to $E_{2}$, 
may be related to reactivity of the HPA to stressful or threatening situations. Affective behavior of rodents is altered by differences in HPA reactivity. For instance, increasing reactivity of the HPA with gestational stress alters affective responses of rodents as adults (as reviewed by Weinstock, 2001). There are sex differences in the response of rodents to gestational stress, such that females show increased vulnerability to its negative effects. Adult females that experienced gestational stress have greater HPA reactivity (Koehl et al, 1999; McCormick et al, 1995; Szuran et al, 2000), anxiety and depression behavior (Frye and Wawrzycki, 2003; Sternberg, 1999; Takahashi et al, 1992; Weinstock et al, 1992; Weinstock, 1997) and hippocampal cell loss (Schmitz et al, 2002), than do gestationally stressed males or nonstressed conspecifics. $\mathrm{E}_{2}$ 's effects on antianxiety, antidepressive, and sexual behavior are attenuated in gestationally stressed compared to nonstressed female rats (Frye and Orecki, 2002a, b; Frye and Wawrzycki, 2003; Walf et al, 2003). Thus, sex and individual differences in affective responses may be altered by stress, but whether there is a relationship between $\mathrm{E}_{2}$ 's effects on the HPA and affective behavior needs further clarification.

$\mathrm{E}_{2}$ may contribute to the normal functioning of the HPA response. There are sex differences in basal and stressinduced glucocorticoids among people and rodents, such that males typically have lower levels of glucocorticoids than do females (Critchlow et al, 1963; Gallucci et al, 1993; Handa et al, 1994; Jezova et al, 1996; Kitay, 1963). High physiological levels of $\mathrm{E}_{2}$ among women increase basal concentrations of cortisol and adrenocorticotrophic hormone (ACTH; Altemus et al, 2001; Genazzani et al, 1975; Marinari et al, 1976). Following a precipitous decline in the high, sustained levels of $\mathrm{E}_{2}$ and progestins during pregnancy, postpartum women experience greater HPA axis response to stressors (Altemus et al, 2001; reviewed by Carter et al, 2001). Naturally receptive rats have higher basal and stress-induced plasma corticosterone levels compared to rats in other stages of the estrous cycle (Carey et al, 1995; Figueiredo et al, 2002; Frye and Bayon, 1999; Raps et al, 1971; Viau and Meaney, 1991). Although HPA activity is increased with an acute rise in $\mathrm{E}_{2}$ during proestrus, it is dampened with stable physiological $\mathrm{E}_{2}$ levels during lactation (Sibolboro Mezzacappa et al, 2003; Viau and Meaney, 1991). These data suggesting that the HPA is altered by changes in endogenous $\mathrm{E}_{2}$ levels are tempered by evidence for progestins' clear effects to reduce HPA reactivity (Roca et al, 2003; Patchev et al, 1996). It may be that $E_{2}$ 's effects to increase production of neuroactive progestins ultimately increases inhibitory feedback on the HPA response (Cheng and Karavolas, 1973; Frye and Rhodes, 2005; Vongher and Frye, 1999).

Experience and regimen-dependent effects of $E_{2}$ for HPA response. Just as there are regimen-dependent effects of $\mathrm{E}_{2}$ for affective behavior (ie acute, lower dosages decrease anxiety and depression), there are similar patterns observed for $\mathrm{E}_{2}$ 's modulation of the HPA response. Administration of $\mathrm{E}_{2}$ to individuals with low endogenous $\mathrm{E}_{2}$ levels alters HPA response depending on prior experience and regimen. For instance, although there is some evidence for stress responses to be enhanced among women with lower $E_{2}$ levels (postnatural or surgical menopause; De Leo et al, $1998)$, there is also evidence that $\mathrm{E}_{2}$ therapy to postmenopausal women increases cortisol levels (Duka et al, 2000). Acute $\mathrm{E}_{2}$ administration to ovx rats reduces basal and/or stress-induced corticosterone levels, but administration of higher $\mathrm{E}_{2}$ dosages or more chronic regimen produces the opposite effect (Burgess and Handa, 1992; Carey et al, 1995; Dayas et al, 2000; Kitay, 1963; McCormick et al, 2002; Redei et al, 1994; Viau and Meaney, 1991; Walf and Frye, 2005a; Young et al, 2001). Prior exposure to $E_{2}$ alters stress responses. Primiparous and multiparous rats have decreased restraint stress-induced c-Fos expression in limbic regions, such as the hippocampus, compared to nulliparous rats (Wartella et al, 2003). Notably, acute stress exposure can increase biosynthesis of $\mathrm{E}_{2}$ (Shors et al, 1999). Thus, there may be an optimal level of $E_{2}$ to dampen HPA reactivity, and whether this effect occurs concomitant with changes in anxiety and depressive behavior is of interest. Given these regimen-dependent effects of $E_{2}$ on HPA function, it is essential to manipulate and measure both $\mathrm{E}_{2}$ and corticosterone responses to begin to address this question.

Our laboratory investigated whether the regimen-dependent effects of $E_{2}$ for anxiety and depression behavior may be modified by changes in HPA reactivity. Ovx rats were administered vehicle, low $(2 \mu \mathrm{g})$, moderate (5 or $10 \mu \mathrm{g})$, or high $(20$ or $50 \mu \mathrm{g})$ doses of $\mathrm{E}_{2}$. Anxiety and depression behavior and $\mathrm{E}_{2}$ and corticosterone levels were measured following two types of HPA manipulation (acute stress or adrenalectomy (ADX) with administration of low or high corticosterone concentration in drinking water or saline; Walf and Frye, 2005a). Antianxiety- and antidepressant-like effects of 5 or $10 \mu \mathrm{g} \mathrm{E}_{2}$, compared to lower or higher dosages, occurred concomitant with lower corticosterone levels. There was an interaction between $\mathrm{E}_{2}$ dosage and stress exposure for anxiety and depression behavior, such that antianxiety- and antidepressant-like effects of 5 or $10 \mu \mathrm{g} \mathrm{E}_{2}$, but not lower or higher dosages of $\mathrm{E}_{2}$, were attenuated with acute restraint stress, which increased plasma corticosterone. As well, reduced anxiety and depression behavior due to administration of moderate dosage of $\mathrm{E}_{2}$ was not apparent in $\mathrm{ADX}$ rats that were not administered corticosterone or those administered high dosages of corticosterone, which produced stress-like plasma corticosterone levels. Together, these data suggest that negative feedback of the HPA may be important for $E_{2}$ 's effects on anxiety and depression. Indeed, $\mathrm{E}_{2}$ can directly act on the adrenal gland and central HPA targets to alter HPA feedback (Figueiredo et al, 2002, 2003). It is likely that $\mathrm{E}_{2}$ is acting via central HPA targets upstream of corticosterone. First, effects of ADX and corticosterone-replacement suggest that an intact HPA-negative feedback mechanism is required for these effects of $E_{2}$ and corticosterone replacement does not abrogate all effects of ADX. Second, restraint stress, which increases negative feedback, attenuates $\mathrm{E}_{2}$ 's antianxiety- and antidepressant-like effects. However, the restraint paradigm that we utilized produced only modest increases in plasma corticosterone. Together, these data suggest that $E_{2}$ 's regimen-dependent effects on affective behavior that occur concomitant with, and may rely on, HPA responses may underlie some of the individual differences in response to $E_{2}$. These data further suggest 
which brain areas that may be targets of $\mathrm{E}_{2}$ for these effects, namely the hippocampus and amygdala.

\section{CNS Sites that are Involved in $E_{2}$ 's Effects on Anxiety and Depressive Behavior}

Although the brain areas that mediate central actions of $E_{2}$ for affective behavior are not well defined, the hippocampus and amygdala are putative sites for these effects. Both the amygdala and hippocampus have long been considered important components of the limbic system and regulators of the HPA response (LeDoux, 2000; Walker et al, 2003). Manipulations in these regions of progestins in female rats and androgens in male rats produces robust changes in anxiety/fear and depression behavior (Bitran et al, 1999, 2000; Edinger and Frye, 2004, 2005; Frye and Walf, 2002, 2004a, b; Rhodes and Frye, 2001; Walf and Frye, 2003; Walf et al, 2005), suggesting a role of these brain regions for other steroids' effects on anxiety and depression.

The role of the hippocampus in $E_{2}$ 's effects on anxiety and depression behavior. The hippocampus is a target of $\mathrm{E}_{2}$. Radioactively labeled $E_{2}$ injected into female rats is concentrated in the hippocampus (Pfaff and Keiner, 1973). $\mathrm{E}_{2}$ administration increases activity in the hippocampus as evidenced by increased immunohistochemical staining for the immediate early gene, c-fos (Rudick and Woolley, 2000). $\mathrm{E}_{2}$ also alters the plasticity of the hippocampus. Levels of brain-derived neurotrophic factor in the hippocampus fluctuate across the estrous cycle and are increased in ovx rats following administration of $E_{2}$ (Gibbs, 1998, 1999). The density of dendritic spines in the hippocampus are increased in naturally receptive rats, or after $E_{2}$ administration to ovx rats (Gould et al, 1990; MacLusky et al, 2005; Woolley et al, 1990; Woolley and McEwen, 1993). Notably, typical antidepressant treatments increase neurogenesis in the hippocampus (reviewed by Duman et al, 2001).

Behaviors that rely on hippocampal function are sensitive to $E_{2}$ treatment. $E_{2}$ administration enhances performance in several hippocampus-dependent cognitive tasks among young ovx or aged female rodents (Bowman et al, 2002; Frick et al, 2002; Frye et al, 2005; Frye and Rhodes, 2002; Gibbs et al, 2004; Li et al, 2004; Luine et al, 2003; as reviewed by Packard, 1998; Rhodes and Frye, 2004). Thus, the hippocampus is a likely target of $\mathrm{E}_{2}$ for its behavioral effects.

Our laboratory has investigated whether the hippocampus is an intergral brain site for $E_{2}$ 's effects for anxiety and depression behavior by directly administering $\mathrm{E}_{2}$ to this region. $E_{2}$, when administered to the hippocampus or subcutaneously, increased antianxiety- and antidepressantlike behavior compared to vehicle administration. Bilateral application of cannulae inserts filled with $17 \beta-\mathrm{E}_{2}$ to the dorsal hippocampus increased central entries made in the open field, increased time spent on the open arms of the elevated plus maze, and decreased time spent immobile in the forced swim test (see Figure 1). Importantly, this intrahippocampal $\mathrm{E}_{2}$ regimen produced similar behavioral effects as did the systemic $\mathrm{E}_{2}$ regimen utilized, which produces physiological circulating $\mathrm{E}_{2}$ levels (Walf and Frye, $2005 b$ ). The same regimen of $E_{2}$ to the ventral tegmental area did not alter open field central entries (intra-VTA $\mathrm{E}_{2}$ :
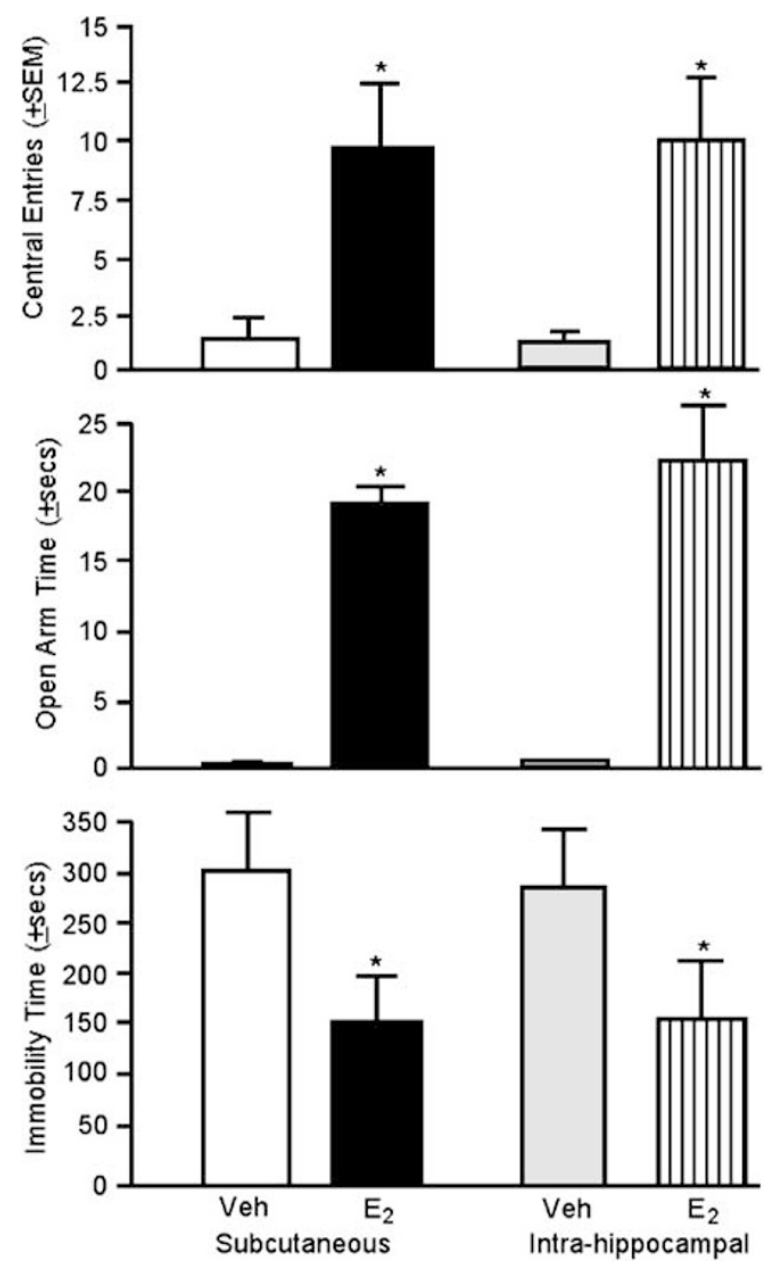

Figure I Administration of $E_{2}$ decreases anxiety and depression behavior. $E_{2}$ or vehicle alone was administered either subcutaneously or intrahippocampally. $E_{2}$ increased central open field entries (top panel) and time spent in the open arms of the plus maze (center panel). $E_{2}$ decreased the duration of immobility in the forced swim test (bottom panel). Error bars indicate one SEM. * $p<0.05, E_{2}$ vs vehicle.

$2.0 \pm 1.0$, intra-VTA vehicle: $4.6 \pm 1.7$ ) or elevated plus maze open arm time (intra-VTA $E_{2}: 1.0 \pm 1.0 \mathrm{~s}$, intra-VTA vehicle: $1.0 \pm 1.0 \mathrm{~s})$ of ovx rats ( $n=6-7$ per group). Thus, the hippocampus is a target for $\mathrm{E}_{2}$ 's antianxiety- and antidepressant-like effects.

The role of the amygdala in $E_{2}$ 's effects on anxiety and depression behavior. The amygdala is another limbic region that is sensitive to $E_{2}$ treatment. First, cells in the amygdala have high concentrations of radioactively labeled $\mathrm{E}_{2}$ after systemic injection into female rats (Pfaff and Keiner, 1973). Second, $\mathrm{E}_{2}$ administration increases c-fos immunoreactivity in the medial amygdala (Greco et al, 2003a, b; Insel, 1990). Third, the number of synapses on dendritic shafts in amygdala neurons are increased by $\mathrm{E}_{2}$ treatment (Nishizuka and Arai, 1982) and dendritic spine density in the medial amygdala fluctuates across the estrous cycle of rats (RasiaFilho et al, 2004). These data suggest that the amygdala is an $\mathrm{E}_{2}$-sensitive CNS site that may play a role in $\mathrm{E}_{2}$ 's effects on anxiety and depression behavior. 
$\mathrm{E}_{2}$ alters behavioral responses of rodents in affective tasks that involve the amygdala. Similar effects of subcutaneous injection and intra-amygdala $E_{2}$ administration to ovx rats are observed in models of fear and nociception, such that both enhance stress-induced analgesia following acute exposure to a predator odor (Walf and Frye, 2003). Thus, the amygdala is a likely target for $\mathrm{E}_{2}$ 's functional effects on other emotional responses, such as anxiety/depression.

Our laboratory has investigated the role of the amygdala in $\mathrm{E}_{2}$ 's modulation of anxiety and depressive behavior. $\mathrm{E}_{2}$ to the medial amygdala, and not missed sites, produces similar antianxiety- and antidepressant-like effects as systemic dosing of $\mathrm{E}_{2}$ that produces physiological plasma $\mathrm{E}_{2}$ levels. Intra-amygdala $\mathrm{E}_{2}$ increased central entries in the open field and time spent on the open arms of the elevated plus maze (Frye and Walf, 2004a). The same regimen of $E_{2}$ to the amygdala also decreases depressive behavior. $\mathrm{E}_{2}$ to the amygdala decreases time spent immobile $(217.6 \pm 42.2 \mathrm{~s})$ compared to intra-amygdala vehicle $(273.6 \pm 26.6 \mathrm{~s})$. Similar effects of intra-amygdala and subcutaneous $E_{2}$ administration suggest that the amygdala is a target of $E_{2}$ for its antianxiety- and antidepressant-like effects.

These data suggest $E_{2}$ acts in the hippocampus and amygdala to decrease anxiety and depression behavior. A question that remains is the mechanism(s) of $E_{2}$ for these effects.

\section{Putative Mechanisms for $\mathrm{E}_{2}$ 's Effects on Anxiety and Depression}

ERs as putative substrates for $E_{2}$ 's effects on anxiety and depressive behavior. $\mathrm{E}_{2}$ may act in the hippocampus and/or amygdala to reduce anxiety and depressive behavior via traditional ligand-dependent actions at intracellular ERs. Specific binding sites, which eventually became known as ERs, for $\mathrm{E}_{2}$ were identified over 40 years ago (Jensen and Jacobsen, 1962). Like other steroid receptors, ERs function as transcription factors and their activity is modulated by $E_{2}$. $E_{2}$ binds to intracellular ERs, which may be located in the cytoplasm or nucleus, in a ligand-dependent manner, and, subsequently, ERs bind DNA as homodimers with the $E_{2}$ response element or the activator protein 1-binding site. This results in transcription and translation of new proteins that carry out the cell's functional response (reviewed by Giguere, 2003; Falkenstein et al, 2000; O'Malley and Means, 1974). Indeed, intracellular ERs have been localized to the amygdala and hippocampus (Shughrue et al, 1997, 1998) and $\mathrm{E}_{2}$ 's effects at ERs in both regions are of interest.

To address whether $E_{2}$ is acting at intracellular ERs in the hippocampus or amygdala to reduce anxiety and depressive behavior, our laboratory investigated the effects of blocking these receptors on anxiety and depression behavior of naturally receptive rats. Rats were administered bilateral infusions of a specific ER antagonist, ICI 182,780 (10 $\mu \mathrm{g}$ in $1 \mu \mathrm{l}$ saline; Frye and Rhodes, 2002) to the dorsal hippocampus or medial amygdala $2 \mathrm{~h}$ prior to testing in the open field, elevated plus maze, and forced swim test. Compared to vehicle infusions, infusions of ICI 182,780 to the hippocampus of naturally receptive rats reduced central open field entries and open arm activity, and increased immobility in the forced swim test (see Figure 2). Infusions of ICI 182,780 to the amygdala-produced behavior that was
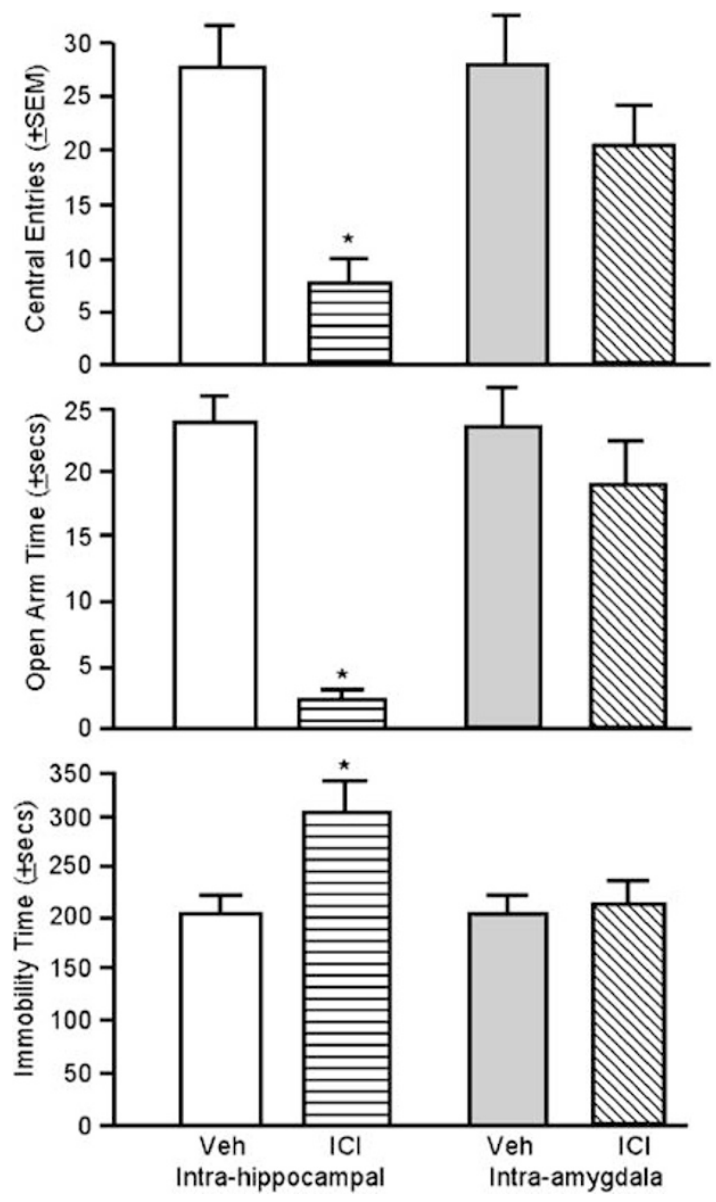

Figure 2 Administration of an $E R$ antagonist (ICl |82,780) to the hippocampus, but not the amygdala, increases anxiety and depression behavior. The antagonist applied to hippocampus decreased central open field entries (top panel) and time spent on the open arms of the plus maze (middle panel) but increased time spent immobile in the forced swim test (bottom panel). Error bars indicate one SEM. ${ }^{*} p<0.05$, antagonist vs vehicle.

not different from vehicle infusions. These data suggest that intracellular ERs in the hippocampus, but not the amygdala, are critical for the antianxiety- and antidepressant-like effects of $\mathrm{E}_{2}$. However, it is also possible that ICI 182,780's effects in the hippocampus were due to actions at membrane ERs ( $\mathrm{Gu}$ et al, 1999), which has yet to be thoroughly addressed.

The role of $E R$ isoforms, $\alpha$ and $\beta$, for $E_{2}$ 's effects on anxiety and depressive behavior. The variable effects of $\mathrm{E}_{2}$ on affective behavior may be related to $E_{2}$ 's actions at two distinct ERs isoforms. In 1996, a second form of ER was identified (ER $\beta$; Kuiper et al, 1996; Tremblay et al, 1997). $\operatorname{ER} \alpha$ and $\operatorname{ER} \beta$ have distinct $\mathrm{N}$-terminal regions and share similar DNA- and ligand-binding domains (Tremblay et al, 1997), but they are encoded by different genes (Green et al, 1986; Kuiper et al, 1996), differentially alter gene regulation, (Kuiper et al, 1997, 1998; Mitchner et al, 1998; Paech et al, 1997; Tena-Sempere et al, 2004), and have distinct temporal patterns of expression in the body and brain (reviewed by Gustafsson, 2003; Shughrue et al, 1997). Notably, ER $\alpha$ and $\operatorname{ER} \beta$ have been localized in the hippocampus and amygdala 
(Greco et al, 2003a, b; Osterlund and Hurd, 1998; Shughrue et al, 1997, 1998), supporting further investigation of the ER-isoform-specific mechanisms of $\mathrm{E}_{2}$ in these regions.

$\operatorname{ER} \beta$ may be required for the antianxiety- and antidepressant-like effects of $E_{2}$. Studies investigating the effects of $\operatorname{ER} \beta$ gene knockout suggest that $\operatorname{ER} \beta$ is necessary for $\mathrm{E}_{2}$ 's actions on affective behavior. Female homozygous $\operatorname{ER} \beta$ knockout mice do not respond to $\mathrm{E}_{2}$ with decreased anxiety (greater open arm activity in the plus maze) or depressive (greater immobility in the forced swim test) behavior as do their wild-type littermates; however, there is some evidence that $\operatorname{ER} \beta$ knockout mice have increased anxiety behavior irrespective of $\mathrm{E}_{2}$ treatment (Imwalle et al, 2005; Krezel et al, 2001; Rocha et al, 2005). We have recently investigated the effects of $10 \mu \mathrm{g} 17 \beta-\mathrm{E}_{2}$ subcutaneous injections to adult, intact wild-type and homozygous and heterozygous $\operatorname{ER} \beta$ knockout mice when administered $48 \mathrm{~h}$ prior to testing in the open field and elevated plus maze. $\mathrm{E}_{2}$ administration to wild-type, but not $\mathrm{ER} \beta$ knockout mice, increase antianxiety behavior in the open field and elevated plus maze compared to vehicle (Figure 3).

Administration of dietary phytoestrogens with a greater affinity for $\operatorname{ER} \beta$ than $\mathrm{ER} \alpha$, such as genistein and daidzein, decrease anxiety behavior. Genistein exposure from gestation to adulthood decreases anxiety behavior of male and female rats in the elevated plus maze (Lephart et al, 2002; Lund and Lephart, 2001). Supplements containing daidzein and genistein for 1 or 2 weeks in adulthood increased open arm activity in adult female rats (Patisaul et al, 2005). However, exposure to genistein or daidzein for 18 days reduced time spent interacting with a conspecific and open
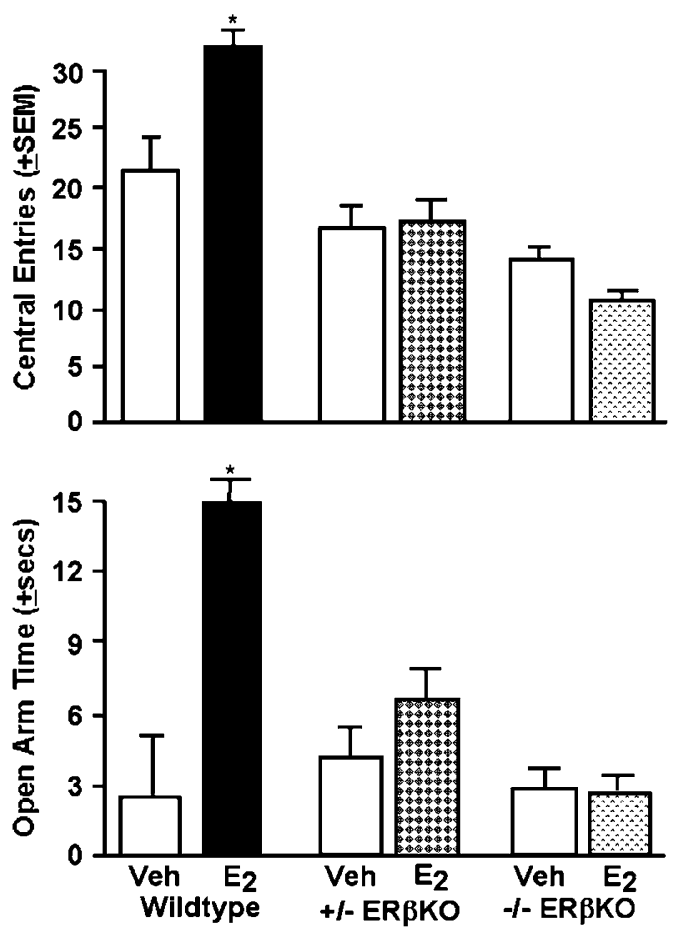

Figure 3 Administration of $E_{2}$ to wild-type, but not heterozygous ( + / $-\mathrm{ER} \beta \mathrm{KOO}$ ) or homozygous (-l-ER $\beta K \mathrm{KO}) \mathrm{ER} \beta$ knockout mice, increases central entries in the open-field (top) and open arm duration (bottom) compared to vehicle administration. ${ }^{*} p<0.05, E_{2}$ vs vehicle. arm activity in the plus maze, and significantly increased stress-induced corticosterone secretion (Forsling et al, 2003; Hartley et al, 2003). These differences may reflect the effects of exposure duration and/or concentration of phytoestrogens and the resulting effects at $\operatorname{ER} \alpha$ and/or $\operatorname{ER} \beta$ to alter the HPA. Although the ability of stress to alter individuals' response to $E_{2}$ may not clearly reflect a direct relationship of the HPA and $E_{2}$ 's effects on anxiety and depression, there is evidence of a regulatory role of ERs, in particular $\operatorname{ER} \beta$, in the HPA. The paraventricular nucleus of the hypothalamus has high levels of $\operatorname{ER} \beta$ mRNA and corticotropin-releasing hormone cells coexpress $\operatorname{ER} \beta$ (Isgor et al, 2003; Suzuki and Handa, 2004). Administration of an ER antagonist, tamoxifen, which has antagonistic actions via $\operatorname{ER} \beta$, blocks the ability of systemic $\mathrm{E}_{2}$ to reduce stress-induced ACTH and corticosterone levels of ovx rats (Watanabe et al, 1997; Young et al, 2001). Indeed, actions at $\operatorname{ER} \beta$ may reduce HPA reactivity more than that observed with $E R \alpha$. In support, stress-induced corticosterone levels of ovx rats are lower following administration of an $\operatorname{ER} \beta$-selective ligand (DPN) compared to $17 \beta-\mathrm{E}_{2}$ or a ER $\alpha$-selective ligand (PPT; Lund et al, 2005). Thus, some of the exposure-dependent effects of phytoestrogens with greater activity at $\operatorname{ER} \beta$ than $\operatorname{ER} \alpha$ on anxiety may be related to differential ability of these receptor isoforms to modulate the HPA.

SERMs that have differential binding affinity for $E R \alpha$ and $\operatorname{ER} \beta$ provide a tool to investigate the importance of ER isoforms for functional effects of $E_{2}$. We and others have shown that administration of $17 \beta-\mathrm{E}_{2}$ (which has high affinity for both $\operatorname{ER} \alpha$ and $\operatorname{ER} \beta$ ), compared to vehicle or $\mathrm{ER} \alpha$-specific SERMs, similarly increases antianxiety and antidepressant-like effects in several tasks as do SERMs with greater specificity for $\operatorname{ER} \beta$ than $\mathrm{ER} \alpha$ (Lund et al, 2005; Walf et al, 2004; Walf and Frye, 2005b). The potential for a modulatory action of $\operatorname{ER} \beta$ on $\operatorname{ER} \alpha$ and the ability of $\operatorname{ER} \alpha$ and $\operatorname{ER} \beta$ to form functional heterodimers (reviewed by Giguere, 2003; Lindberg et al, 2003) are factors that may underlie $E_{2}$ 's actions involving $\operatorname{ER} \beta$ in the hippocampus for affective behavior and requires further investigation.

Another possibility is that $\mathrm{E}_{2}$ may act by targeting mitochondria and altering cellular energy stores. $\operatorname{ER} \beta$ have been localized to the mitochondria in peripheral and CNS tissue (Yang et al, 2004). Neurons are dependent almost entirely on mitochondrial ATP for their energy demands. It has been suggested that mitochondria may be important targets underlying $\mathrm{E}_{2}$ 's beneficial effects (Simpkins et al, 2005). An intriguing question that remains to be investigated is whether actions of $\mathrm{E}_{2}$ at mitochondrial $\operatorname{ER} \beta$ may underlie its modulatory effects on anxiety and depression behavior.

Other novel mechanisms for $E_{2}$ 's effects involving membrane actions. ERs, specifically $\mathrm{ER} \beta$, are putative targets of $\mathrm{E}_{2}$ for its functional effects, but there are other possible mechanisms by which $\mathrm{E}_{2}$ can influence anxiety and depression behavior. Evidence that an ER antagonist to the amygdala does not alter anxiety or depressive behavior of naturally receptive rats suggests that $E_{2}$ may act at substrates other than intracellular ERs.

One target of $\mathrm{E}_{2}$ in the amygdala may be the opioid system. $\mathrm{E}_{2}$ increases proenkephalin messenger ribonucleic 
acid (mRNA) levels in the ventral medial hypothalamus of female rats, thereby enhancing sexual receptivity (Lauber et al, 1990; Romano et al, 1988). Notably, $\mathrm{E}_{2}$ increases preproenkephalin mRNA in the medial amygdala (Sinchak et al, 2000). Although modulation of the opioid system may underlie some of the effects of $E_{2}$ in this region, $E_{2}$ may also target other membrane substrates in the amygdala.

Rapid effects of $E_{2}$ suggest that $E_{2}$ may act through a membrane-associated ER mechanism. Effects of $E_{2}$ through intracellular ERs are expected to have a minimum latency of 10-15 min (Pfaff and McEwen, 1983), implying that rapid effects of $E_{2}$ occur through membrane ERs. In dissociated hippocampal cells, $E_{2}$ increases kainate-induced currents in $3 \mathrm{~min}$ ( $\mathrm{Gu}$ and Moss, 1996). Rapid actions of $\mathrm{E}_{2}$ may involve membrane ERs, membrane targets, and/or activation of several signal transduction pathways, such as the mitogenactivating protein kinase, extracellular signal-regulated kinase, phosphatidylinositol-3-kinase, or adenylyl cyclase cascades (Beyer et al, 2002; Kelly and Levin, 2001; Moss and Gu, 1999; Nilsen et al, 2002; Toran-Allerand et al, 2002; Wade et al, 2001; Watters et al, 1997). Thus, it may be that $\mathrm{E}_{2}$ 's is acting at membrane targets and/or signal transduction pathways in the hippocampus and amygdala to alter affective behavior.

Possible interactions of $E_{2}$ 's actions in the hippocampus and amygdala for affective behavior. Another possibility to consider is that there is a convergence of $E_{2}$ 's actions through intracellular ERs and rapid, membrane-mediated effects in the hippocampus and amygdala. Studies investigating the circuitry of the stress response have demonstrated that activation of both the hippocampus and amygdala alter the functional response to stressors (as reviewed by Herman et al, 2003, 2004). In vivo and in vitro work demonstrates that $\mathrm{E}_{2}$ may act at membrane ERs that potentiate its effects through nuclear ERs and require activation of protein kinase A or C for its effects (Kow and Pfaff, 2004; Vasudevan et al, 2001). It may be that $\mathrm{E}_{2^{-}}$ mediated changes in anxiety and depression behavior involve its binding at membrane receptors and subsequent activation of downstream signaling molecules in the amygdala that may depend on an interaction with intracellular ERs in the hippocampus.

\section{Conclusions}

In summary, there is some evidence for $\mathrm{E}_{2}$ to have beneficial effects to improve mood among women and decrease anxiety and depression behavior of female rodents. There are some limitations to these studies related to the regimenand/or exposure-dependent effects of $E_{2}$ for anxiety and depression and/or the involvement of HPA responses. Limbic regions, such as the hippocampus and/or amygdala, that have connections to the HPA, may be targets for $E_{2}$ 's effects on anxiety and depression. $\mathrm{E}_{2}$ 's actions at intracellular ERs, in particular ER $\beta$, may be critical for these effects. Furthermore, the effects of $E_{2}$ at other substrates, such as membrane ERs or rapid actions involving signal transduction molecules, may also be important.

Determining the effects, targets, and mechanisms of $\mathrm{E}_{2}$ 's actions on affective behavior has great clinical significance. Increasing life expectancy of women, together with a relatively constant age of menopause, has resulted in women now spending about one-third to one-half of their lives with levels of endogenous $\mathrm{E}_{2}$ that are low or at nadir (reviewed by Wise, 2003). It is likely that more women will use $\mathrm{E}_{2}$-based therapies to relieve some symptoms associated with $\mathrm{E}_{2}$ decline. However, recent clinical trials examining effects of $E_{2}$ therapy among postmenopausal women have failed to support beneficial effects of $E_{2}$ for cognition or mood (Brunner et al, 2005; Hays et al, 2003; Rapp et al, 2003; Rossouw et al, 2002; Shumaker et al, 2003; Smoller et al, 2003). These findings have led to investigation of antiestrogens and/or SERMs, such as raloxifene and tibolone, as therapeutic agents for menopausal symptoms, such as osteoporosis. However, the effects of these compounds on other symptoms of menopause, such as changes in affect, are not clear. Given the possibility of trophic effects of $E_{2}$ and the differential distribution of ERs in the body, such that proliferative effects of $E_{2}$ are likely to occur through actions involving ER $\alpha$ in the breast and/or mammary tissue (as reviewed by Gustafsson, 2003), it is critical to discern the receptor mechanisms that are important for $E_{2}$ 's antianxiety and antidepressant-like effects. Further research on $E_{2}$ 's mechanisms and brain targets may allow for more informed choices about existing therapies and/or the development of new therapies that have beneficial effects without unwanted proliferative effects.

\section{ACKNOWLEDGEMENTS}

This research was supported by grants from the National Science Foundation (IBN98-96263; IBN03-16083; DBI 0097342), National Institute of Mental Health (MH0676980), Whitehall Foundation (096-010), Ronald McNair Research Program to support minority undergraduates, and a predoctoral grant from the Department of Defense (BC051001 to AAW). Assistance, provided by $\mathrm{Mr} / \mathrm{Ms}$ Acer, Babson, Ballard, Cole, Duffy, Duquette, Edinger, FaganSolis, Fluty, Frederick, Grizaffi, Helmandi, Jeddi, Lee, Marrone, Morimoto, Orecki, Paris, Petralia, Prevost, Rafalski, Rhodes, Sarfoh, Sumida, Thayil, Wawrzycki, and Youmans, is greatly appreciated, as are comments on the manuscript from Drs S Tieman and B Szaro.

\section{REFERENCES}

Ahokas A, Kaukoranta J, Wahlbeck K, Aito M (2001). Estrogen deficiency in severe postpartum depression: successful treatment with sublingual physiologic 17beta-estradiol: a preliminary study. J Clin Psychiatr 62: 332-336.

Almeida OP, Lautenschlager N, Vasikaram S, Leedman P, Flicker L (2005). Association between physiological serum concentration of estrogen and the mental health of community-dwelling postmenopausal women age 70 years and over. Am J Geriatr Psychiatr 13: 142-149.

Altemus M, Redwine LS, Leong YM, Frye CA, Porges SW, Carter CS (2001). Responses to laboratory psychosocial stress in postpartum women. Psychosom Med 63: 814-821.

Baca-Garcia E, Diaz-Sastre C, de Leon J, Saiz-Ruiz J (2000). The relationship between menstrual cycle phases and suicide attempts. Psychosom Med 62: 50-60. 
Bebbington P, Hurry J, Tennant C, Sturt E, Wing JK (1981). The epidemiology of mental disorders in Camberwell. Psychol Med 11: 561-579.

Bebbington PE, Dunn G, Jenkins R, Lewis G, Brugha T, Farrell M et al (1998). The influence of age and sex on the prevalence of depressive conditions: report from the National Survey of Psychiatric Morbidity. Psychol Med 28: 9-19.

Becker JB, Snyder PJ, Miller MM, Westgate SA, Jenuwine MJ (1987). The influence of estrous cycle and intrastriatal estradiol on sensorimotor performance in the female rat. Pharm Biochem Behav 27: 53-59.

Bernardi M, Vergoni AV, Sandrini M, Tagliovini SB (1989). Influence of ovariectomy, estradiol and progesterone on the behavior of mice in an experimental model of depression. Physiol Behav 45: 1067-1068.

Beyer C, Ivanova T, Karolczak M, Kuppers E (2002). Cell typespecificity of nonclassical estrogen signaling in the developing midbrain. J Steroid Biochem Mol Biol 81: 319-325.

Bitran D, Dugan M, Renda P, Ellis R, Foley M (1999). Anxiolytic effects of the neuroactive steroid pregnanolone $(3 \alpha-\mathrm{OH}-5 \beta$ pregnan-20-one) after microinjection in the dorsal hippocampus and lateral septum. Brain Res 850: 217-224.

Bitran D, Foley M, Audette D, Leslie N, Frye CA (2000). Activation of peripheral mitochondrial benzodiazepine receptors in the hippocampus stimulates allopregnanolone synthesis and produces anxiolytic-like effects in the rat. Psychopharmacology 151: 64-71.

Blanchard DC, Shepherd JK, De Padua Carobrez A, Blanchard RJ (1991). Sex effects in defensive behavior: baseline differences and drug interactions. Neurosci Biobehav Rev 15: 461-468.

Blanchard RJ, Agullana R, McGee L, Weiss S, Blanchard DC (1992). Sex differences in the incidence and sonographic characteristics of antipredator ultrasonic cries in the laboratory rat (Rattus norvegicus). J Comp Psychol 106: 270-277.

Bloch M, Daly RC, Rubinow DR (2003). Endocrine factors in the etiology of postpartum depression. Compr Psychiatr 44: 234-246.

Bloch M, Schmidt PJ, Danaceau M, Murphy J, Nieman L, Rubinow DR (2000). Effects of gonadal steroids in women with a history of postpartum depression. Am J Psychiatr 157: 924-930.

Bowman RE, Ferguson D, Luine VN (2002). Effects of chronic restraint stress and estradiol on open field activity, spatial memory, and monoaminergic neurotransmitters in ovariectomized rats. Neuroscience 113: 401-410.

Breslau N, Schultz L, Peterson E (1995). Sex differences in depression: a role for preexisting anxiety. Psychiatr Res $\mathbf{5 8}$ 1-12.

Brunner RL, Gass M, Aragaki A, Hays J, Granek I, Woods N, et al Women's Health Initiative Investigators (2005). Effects of conjugated equine estrogen on health-related quality of life in postmenopausal women with hysterectomy: results from the Women's Health Initiative Randomized Clinical Trial. Arch Intern Med 165: 1976-1986.

Burger HG, Dudley EC, Hopper JL, Shelley JM, Green A, Smith A et al (1995). The endocrinology of the menopausal transition: a cross-sectional study of a population-based sample. J Clin Endocrinol Metab 80: 3537-3545.

Burgess LH, Handa RJ (1992). Chronic estrogen-induced alterations in adrenocorticotropin and corticosterone secretion, and glucocorticoid receptor-mediated functions in female rats. Endocrinology 131: 1261-1269.

Carey MP, Deterd CH, de Koning J, Helmerhorst F, de Kloet ER (1995). The influence of ovarian steroids on hypothalamicpituitary-adrenal regulation in the female rat. J Endocrinol 144: 311-321.

Carlson LE, Sherwin BB, Chertkow HM (2000). Relationships between mood and estradiol $\left(E_{2}\right)$ levels in Alzheimer's disease (AD) patients. J Gerontol B Psychol Sci Soc Sci 55: P47-P53.
Carter CS, Altemus M, Chrousos GP (2001). Neuroendocrine and emotional changes in the post-partum period. Prog Brain Res 133: 241-249.

Cheng YJ, Karavolas HJ (1973). Conversion of progesterone to $5 \alpha$ pregnane-3,20-dione and $3 \alpha$-hydroxy-5 $\alpha$-pregnan-20-one by rat medical basal hypothalami and the effects of estradiol and stage of estrous cycle on the conversion. Endocrinology 93: $1157-1162$.

Cohen LS, Soares CN, Poitras JR, Prouty J, Alexander AB, Shifren JL (2003). Short-term use of estradiol for depression in perimenopausal and postmenopausal women: a preliminary report. Am J Psychiatr 160: 1519-1522.

Contreras CM, Molina M, Saavedra M, Martinez-Mota L (2000). Lateral septal neuronal firing rate increases during proestrusestrus in the rat. Physiol Behav 68: 279-284.

Critchlow V, Liebelt RA, Bar-Sela M, Mountcastle W, Lipscomb HS (1963). Sex difference in resting pituitary-adrenal function in the rat. Am J Physiol 205: 807-815.

Dalton K (1959). Menstruation and acute psychiatric illnesses. Br Med J 34: 148-149.

Daly RC, Danaceau MA, Rubinow DR, Schmidt PJ (2003). Concordant restoration of ovarian function and mood in perimenopausal depression. Am J Psychiatr 160: 1842-1846.

Danilovich N, Harada N, Sairam MR, Maysinger D (2003). Agerelated neurodegenerative changes in the central nervous system of estrogen-deficient follitropin receptor knockout mice. Exp Neurol 183: 559-572.

Dayas CV, Xu Y, Buller KM, Day TA (2000). Effects of chronic oestrogen replacement on stress-induced activation of hypothalamic-pituitary-adrenal axis control pathways. J Neuroendocrinol 12: 784-794.

De Leo V, la Marca A, Talluri B, D’Antona D, Morgante G (1998). Hypothalamo-pituitary-adrenal axis and adrenal function before and after ovariectomy in premenopausal women. Eur J Endocrinol 138: 430-435.

Dean C, Kendell RE (1981). The symptomatology of puerperal illnesses. Br J Psychiatr 139: 128-133.

Diaz-Veliz G, Alarcon T, Espinoza C, Dussaubat N, Mora S (1997). Ketanserin and anxiety levels: influence of gender, estrous cycle, ovariectomy and ovarian hormones in female rats. Pharmacol Biochem Behav 58: 637-642.

Diaz-Veliz G, Butron S, Benavides MS, Dussaubat N, Mora S (2000). Gender, estrous cycle, ovariectomy, and ovarian hormones influence the effects of diazepam on avoidance conditioning in rats. Pharmacol Biochem Behav 66: 887-892.

Ditkoff EC, Crary WG, Cristo M, Lobo RA (1991). Estrogen improves psychological function in asymptomatic postmenopausal women. Obstet Gynecol 78: 991-995.

Duka T, Tasker R, McGowan JF (2000). The effects of 3-week estrogen hormone replacement on cognition in elderly healthy females. Psychopharmacology 149: 129-139.

Duman RS, Nakagawa S, Malberg J (2001). Regulation of adult neurogenesis by antidepressant treatment. Neuropsychopharmacology 25: 836-844.

Earls $\mathrm{F}$ (1987). Sex differences in psychiatric disorders: origins and developmental influences. Psychiatr Dev 5: 1-23.

Easterbrook CC (1900). Organo-therapeutics in mental disease. BMJ 2: 813-823.

Edinger KL, Frye CA (2004). Testosterone's analgesic, anxiolytic, and cognitive-enhancing effects may be due in part to actions of its $5 \alpha$-reduced metabolites in the hippocampus. Behav Neurosci 118: $1352-1364$.

Edinger KL, Frye CA (2005). Testosterone's anti-anxiety and analgesic effects may be due in part to actions of its $5 \alpha$-reduced metabolites in the hippocampus. Psychoneuroendocrinology 30: 418-430.

Estrada-Camarena E, Fernandez-Guasti A, Lopez-Rubalcava C (2003). Antidepressant-like effect of different estrogenic com- 
pounds in the forced swimming test. Neuropsychopharmacology 28: $830-838$.

Falkenstein E, Tillman HC, Christ M, Feuring M, Wehling M (2000). Multiple actions of steriod hormones - a focus on rapid, nongenomic effects. Pharmacol Rev 52: 513-556.

Figueiredo HF, Dolgas CM, Herman JP (2002). Stress activation of cortex and hippocampus is modulated by sex and stage of estrus. Endocrinology 143: 2534-2540.

Figueiredo HF, Dolgas CM, Herman JP (2003). Dissociation of $\mathrm{ACTH}$ and corticosterone responses to stress in female rats treated with estrogen. Horm Behav 44: 48-49.

Frick KM, Fernandez SM, Bulinski SC (2002). Estrogen replacement improves spatial reference memory and increases hippocampal synaptophysin in aged female mice. Neuroscience 115: 547-558.

Frye CA, Bayon LE (1999). Mating stimuli influence endogenous variations in the neurosteroids $3 \alpha, 5 \alpha$-THP and $3 \alpha$-Diol. Neuroendocinol 11: 839-847.

Frye CA, Lacey EH (2001). Posttraining androgens' enhancement of cognitive performance is temporally distinct from androgens' increases in affective behavior. Cogn Affect Behav Neurosci 1: 172-182.

Frye CA, Orecki ZA (2002a). Prenatal stress produces deficits in socio-sexual behavior of cycling, but not hormone-primed, Long-Evans rats. Pharmacol Biochem Behav 73: 53-60.

Frye CA, Orecki ZA (2002b). Prenatal stress alters reproductive responses of rats in behavioral estrus and paced mating of hormone-primed rats. Horm Behav 42: 472-483.

Frye CA, Petralia SM, Rhodes ME (2000). Estrous cycle and sex differences in performance on anxiety tasks coincide with increases in hippocampal progesterone and $3 \alpha, 5 \alpha$-THP. Pharmacol Biochem Behav 67: 587-596.

Frye CA, Rhodes ME (2002). Enhancing effects of estrogen on inhibitory avoidance performance may be in part independent of intracellular estrogen receptors in the hippocampus. Brain Res 956: 285-293.

Frye CA, Rhodes ME (2005). Estrogen-priming can enhance progesterone's anti-seizure effects in part by increasing hippocampal levels of allopregnanolone. Pharmacol Biochem Behav 81: 907-916.

Frye CA, Rhodes ME, Dudek B (2005). Estradiol to aged female or male mice improves learning in inhibitory avoidance and water maze tasks. Brain Res 1036: 101-108.

Frye CA, Walf AA (2002). Changes in progesterone metabolites in the hippocampus can modulate open field and forced swim test behavior of proestrous rats. Horm Behav 41: 306-315.

Frye CA, Walf AA (2004a). Estrogen and/or progesterone systemically or to the amygdala can have anxiety, fear, and pain reducing effects in ovariectomized rats. Behav Neurosci 118: 306-313.

Frye CA, Walf AA (2004b). Hippocampal $3 \alpha, 5 \alpha$-THP may alter depressive behavior of pregnant and lactating rats. Pharmacol Biochem Behav 78: 531-540.

Frye CA, Walf AA, Rhodes ME, Harney JP (2004). Progesterone enhances motor, anxiolytic, analgesic, and antidepressive behavior of wild-type mice, but not those deficient in type 1 $5 \alpha$-reductase. Brain Res 1004: 116-124.

Frye CA, Wawrzycki J (2003). Effect of prenatal stress and gonadal hormone condition on depressive behaviors of female and male rats. Horm Behav 44: 319-326.

Forsling ML, Kallo I, Hartley DE, Heinze L, Ladek R, Coen CW et al (2003). Oestrogen receptor- $\beta$ and neurohypophysial hormones: functional interaction and neuroanatomical localisation. Pharmacol Biochem Behav 76: 535-542.

Galea LA, Lee TT, Kostaras X, Sidhu JA, Barr AM (2002). High levels of estradiol impair spatial performance in the Morris water maze and increase 'depressive-like' behaviors in the female meadow vole. Physiol Behav 77: 217-225.
Galea LA, Wide JK, Barr AM (2001). Estradiol alleviates depressive-like symptoms in a novel animal model of postpartum depression. Behav Brain Res 122: 1-9.

Gallucci WT, Baum A, Laue L, Rabin DS, Chrousos GP, Gold PW et al (1993). Sex differences in sensitivity of the hypothalamicpituitary-adrenal axis. Health Psychol 12: 420-425.

Genazzani AR, Lemarchand-Beraud T, Aubert ML, Felber JP (1975). Pattern of plasma ACTH, hGH, and cortisol during menstrual cycle. J Clin Endocrinol Metab 41: 431-437.

Gibbs RB (1997). Effects of estrogen on basal forebrain cholinergic neurons vary as a function of dose and duration of treatment. Brain Res 757: 10-16.

Gibbs RB (1998). Levels of trkA and BDNF mRNA, but not NGF mRNA, fluctuate across the estrous cycle and increase in response to acute hormone replacement. Brain Res 787: $259-268$

Gibbs RB (1999). Treatment with estrogen and progesterone affects relative levels of brain-derived neurotrophic factor mRNA and protein in different regions of the adult rat brain. Brain Res 844: 20-27.

Gibbs RB, Gabor R, Cox T, Johnson DA (2004). Effects of raloxifene and estradiol on hippocampal acetylcholine release and spatial learning in the rat. Psychoneuroendocrinology 29: 741-748.

Giguere V (2003). Steroid homorne receptor signaling. In: Bradshaw RA, Dennis EA (eds). Handbook of Cell Signaling. Vol. 3. Academic Press: San Diego, CA. pp 35-38.

Goodwin FK, Jamison KR (1990). Manic-Depressive Illness. Oxford University Press: New York, NY.

Gould E, Woolley CS, Frankfurt M, McEwen BS (1990). Gonadal steroids regulate dendritic spine density in hippocampal pyramidal cells in adulthood. J Neurosci 10: 1286-1291.

Greco B, Blasberg ME, Kosinski EC, Blaustein JD (2003a). Response of ER $\alpha$-IR and ER $\beta$-IR cells in the forebrain of female rats to mating stimuli. Horm Behav 43: 444-453.

Greco B, Lubbers LS, Blaustein JD (2003b). Estrogen receptor $\beta$ messenger ribonucleic acid expression in the forebrain of proestrous, pregnant, and lactating female rats. Endocrinology 144: $1869-1875$

Green S, Walter P, Kumar V, Krust A, Bornert JM, Argos P et al (1986). Human oestrogen receptor cDNA: sequence, expression and homology to v-erb-A. Nature 320: 134-139.

Gregoire AJ, Kumar R, Everitt B, Henderson AF, Studd JW (1996). Transdermal oestrogen for treatment of severe postnatal depression. Lancet 347: 930-933.

$\mathrm{Gu}$ Q, Korach KS, Moss RL (1999). Rapid action of $17 \beta$-estradiol on kainate-induced currents in hippocampal neurons lacking intracellular estrogen receptors. Endocrinol 140: 660-666.

$\mathrm{Gu} \mathrm{Q}$, Moss RL (1996). 17 $\beta$-estradiol potentiates kainate-induced currents via activation of the cAMP cascade. J Neurosci 16: $3620-3629$.

Gustafsson JA (2003). What pharmacologists can learn from recent advances in estrogen signaling. Trends Pharmacol Sci 24: $479-485$.

Handa RJ, Burgess LH, Kerr JE, O’Keefe JA (1994). Gonadal steroid hormone receptors and sex differences in the hypothalamopituitary-adrenal axis. Horm Behav 28: 464-476.

Hartley DE, Edwards JE, Spiller CE, Alom N, Tucci S, Seth P et al (2003). The soya isoflavone content of rat diet can increase anxiety and stress hormone release in the male rat. Psychopharmacology 167: 46-53.

Hays J, Ockene JK, Brunner RL, Kotchen JM, Manson JE, Patterson $\mathrm{RE}$ et al, Women's Health Initiative Investigators (2003). Effects of estrogen plus progestin on health-related quality of life. $N$ Engl J Med 348: 1839-1854.

Hayward C, Sanborn K (2002). Puberty and the emergence of gender differences in psychopathology. J Adolesc Health 30: 49-58. 
Heinrich AB, Wolf OT (2005). Investigating the effects of estradiol or estradiol/progesterone treatment on mood, depressive symptoms, menopausal symptoms and subjective sleep quality in older healthy hysterectomized women: a questionnaire study. Neuropsychobiology 52: 17-23.

Herman JP, Figueiredo H, Mueller NK, Ulrich-Lai Y, Ostrander MM, Choi DC et al (2003). Central mechanisms of stress integration: hierarchical circuitry controlling hypothalamopituitary-adrenocortical responsiveness. Front Neuroendocrinol 24: $151-180$.

Herman JP, Mueller NK, Figueiredo H (2004). Role of GABA and glutamate circuitry in hypothalamo-pituitary-adrenocortical stress integration. Ann NY Acad Sci 1018: 35-45.

Hilakivi-Clarke L (1996). Role of estradiol in alcohol intake and alcohol-related behaviors. J Stud Alcohol 57: 162-170.

Imwalle DB, Gustafsson JA, Rissman EF (2005). Lack of functional estrogen receptor $\beta$ influences anxiety behavior and serotonin content in female mice. Physiol Behav 84: 157-163.

Insel TR (1990). Regional induction of c-fos-like protein in rat brain after estradiol administration. Endocrinology 126: $1849-1853$.

Isgor C, Cecchi M, Kabbaj M, Akil H, Watson SJ (2003). Estrogen receptor beta in the paraventricular nucleus of hypothalamus regulates the neuroendocrine response to stress and is regulated by corticosterone. Neuroscience 121: 837-845.

Jenkins R (1987). Sex differences in depression. Br J Hosp Med 38: 485-486.

Jensen EV, Jacobsen HI (1962). Basic guides to the mechanism of estrogen action. Recent Prog Horm Res 18: 387-414.

Jezova D, Jurankova E, Mosnarova A, Kriska M, Skultetyova I (1996). Neuroendocrine response during stress with relation to gender differences. Acta Neurobiol Exp (Warsz) 56: 779-785.

Johnston AL, File SE (1991). Sex differences in animal tests of anxiety. Physiol Behav 49: 245-250.

Kelly MJ, Levin ER (2001). Rapid actions of plasma membrane estrogen receptors. Trends Endocrinol Metab 12: 152-156.

Kessler RC, McGonagle KA, Swartz M, Blazer DG, Nelson CB (1993). Sex and depression in the National Comorbidity Survey. I: Lifetime prevalence, chronicity and recurrence. J Affect Disord 29: 85-96.

Kessler RC, McGonagle KA, Zhao S, Nelson CB, Hughes M, Eshleman S et al (1994). Lifetime and 12-month prevalence of DSM-III-R psychiatric disorders in the United States. Results from the National Comorbidity Survey. Arch Gen Psychiatr 51: 8-19.

Kessler RC, Walters EE (1998). Epidemiology of DSM-III-R major depression and minor depression among adolescents and young adults in the National Comorbidity Survey. Depress Anxiety 7: 3-14.

Kitay JL (1963). Pituitary adrenal function in the rat after gonadectomy and gonadal hormone replacement. Endocrinology 73: $2253-2260$.

Klaiber EL, Broverman DM, Vogel W, Kobayashi Y (1979). Estrogen therapy for severe persistent depressions in women. Arch Gen Psychiatr 36: 550-554.

Klaiber EL, Broverman DM, Vogel W, Peterson LG, Snyder MB (1997). Relationships of serum estradiol levels, menopausal duration, and mood during hormonal replacement therapy. Psychoneuroendocrinology 22: 549-558.

Koehl M, Darnaudery M, Dulluc J, Van Reeth O, Le Moal M, Maccari S (1999). Prenatal stress alters circadian activity of hypothalamo-pituitary-adrenal axis and hippocampal corticosteroid receptors in adult rats of both gender. J Neurobiol 40: 302-315.

Koss WA, Gehlert DR, Shekhar A (2004). Different effects of subchronic doses of 17-beta estradiol in two ethologically based models of anxiety utilizing female rats. Horm Behav 46: 158-164.
Kow LM, Pfaff DW (2004). The membrane actions of estrogens can potentiate their lordosis behavior-facilitating genomic actions. Proc Natl Acad Sci 101: 12354-12357.

Krezel W, Dupont S, Krust A, Chambon P, Chapman PF (2001). Increased anxiety and synaptic plasticity in estrogen receptor $\beta$-deficient mice. Proc Natl Acad Sci 98: 12278-12282.

Kuiper GG, Carlsson B, Grandien K, Enmark E, Haggblad J, Nilsson S et al (1997). Comparison of the ligand binding specificity and transcript tissue distribution of estrogen receptors $\alpha$ and $\beta$. Endocrinology 138: 863-870.

Kuiper GG, Enmark E, Pelto-Huikko M, Nilsson S, Gustafsson JA (1996). Cloning of a novel receptor expressed in rat prostate and ovary. Proc Natl Acad Sci 93: 5925-5930.

Kuiper GG, Lemmen JG, Carlsson B, Corton JC, Safe SH, van der Saag PT et al (1998). Interaction of estrogenic chemicals and phytoestrogens with estrogen receptor $\beta$. Endocrinology 139: 4252-4263.

Lauber AH, Romano GJ, Mobbs CV, Howells RD, Pfaff DW (1990). Estradiol induction of proenkephalin messenger RNA in hypothalamus: dose-response and relation to reproductive behavior in the female rat. Brain Res Mol Brain Res 8: 47-54.

LeDoux JE (2000). Emotion circuits in the brain. Annu Rev Neurosci 23: 155-184.

Lephart ED, West TW, Weber KS, Rhees RW, Setchell KD, Adlercreutz $\mathrm{H}$ et al (2002). Neurobehavioral effects of dietary soy phytoestrogens. Neurotoxicol Teratol 24: 5-16.

Lewinsohn PM, Rohde P, Seeley JR (1998). Major depressive disorder in older adolescents: prevalence, risk factors, and clinical implications. Clin Psychol Rev 18: 765-794.

Li C, Brake WG, Romeo RD, Dunlop JC, Gordon M, Buzescu R et al (2004). Estrogen alters hippocampal dendritic spine shape and enhances synaptic protein immunoreactivity and spatial memory in female mice. Proc Natl Acad Sci 101: 2185-2190.

Lindberg MK, Moverare S, Skrtic S, Gao H, Dahlman-Wright K, Gustafsson JA et al (2003). Estrogen receptor (ER)- $\beta$ reduces $\mathrm{ER} \alpha$-regulated gene transcription, supporting a 'ying yang' relationship between $\mathrm{ER} \alpha$ and $\mathrm{ER} \beta$ in mice. Mol Endocrinol 17: 203-208.

Luine VN, Jacome LF, Maclusky NJ (2003). Rapid enhancement of visual and place memory by estrogens in rats. Endocrinology 144: 2836-2844.

Luine VN, Richards ST, Wu VY, Beck KD (1998). Estradiol enhances learning and memory in a spatial memory task and effects levels of monoaminergic neurotransmitters. Horm Behav 34: 149-162.

Lund TD, Lephart ED (2001). Dietary soy phytoestrogens produce anxiolytic effects in the elevated plus-maze. Brain Res 913: 180-184.

Lund TD, Rovis T, Chung WC, Handa RJ (2005). Novel actions of estrogen receptor beta on anxiety-related behaviors. Endocrinology 146: 797-807.

MacLusky NJ, Luine VN, Hajszan T, Leranth C (2005). The $17 \alpha$ and $17 \beta$ isomers of estradiol both induce rapid spine synapse formation in the CA1 hippocampal subfield of ovariectomized female rats. Endocrinology 146: 287-293.

Marcondes FK, Miguel KJ, Melo LL, Spadari-Bratfisch RC (2001). Estrous cycle influences the response of female rats in the elevated plus-maze test. Physiol Behav 74: 435-440.

Marinari KT, Leshner AI, Doyle MP (1976). Menstrual cycle status and adrenocortical reactivity to psychological stress. Psychoneuroendocrinology 1: 213-218.

Martinez-Mota L, Estrada-Camarena E, Lopez-Rubalcava C, Contreras CM, Fernandez-Guasti A (2000). Interaction of desipramine with steroid hormones on experimental anxiety. Psychoneuroendocrinology 25: 109-120.

Marvan ML, Chavez-Chavez L, Santana S (1996). Clomipramine modifies fluctuations of forced swimming immobility in different phases of the rat estrous cycle. Arch Med Res 27: 83-86. 
Marvan ML, Santana S, Chavez Chavez L, Bertran M (1997). Inescapable shocks accentuate fluctuations of forced swimming immobility in different phases of the rat estrous cycle. Arch Med Res 28: 369-372.

McCarthy MM, Felzenberg E, Robbins A, Pfaff DW, SchwartzGiblin S (1995). Infusions of diazepam and allopregnanolone into the midbrain central gray facilitate open-field behavior and sexual receptivity in female rats. Horm Behav 29: 279-295.

McCarthy MM, McDonald CH, Brooks PJ, Goldman D (1996). An anxiolytic action of oxytocin is enhanced by estrogen in the mouse. Physiol Behav 60: 1209-1215.

McCormick CM, Linkroum W, Sallinen BJ, Miller NW (2002). Peripheral and central sex steroids have differential effects on the HPA axis of male and female rats. Stress 5: 235-247.

McCormick CM, Smythe JW, Sharma S, Meaney MJ (1995). Sex-specific effects of prenatal stress on hypothalamic-pituitary-adrenal responses to stress and brain glucocorticoid receptor density in adult rats. Brain Res Dev Brain Res 84: 55-61.

Miller KJ, Conney JC, Rasgon NL, Fairbanks LA, Small GW (2002). Mood symptoms and cognitive performance in women estrogen users and nonusers and men. J Am Geriatr Soc 50: 1826-1830.

Mitchner NA, Garlick C, Ben-Jonathan N (1998). Cellular distribution and gene regulation of estrogen receptors $\alpha$ and $\beta$ in the rat pituitary gland. Endocrinology 139: 3976-3983.

Mora S, Dussaubat N, Diaz-Veliz G (1996). Effects of the estrous cycle and ovarian hormones on behavioral indices of anxiety in female rats. Psychoneuroendocrinology 21: 609-620.

Morgan MA, Pfaff DW (2001). Effects of estrogen on activity and fear-related behaviors in mice. Horm Behav 40: 472-482.

Morgan MA, Pfaff DW (2002). Estrogen's effects on activity, anxiety, and fear in two mouse strains. Behav Brain Res 132: 85-93.

Morrison MF, Kallan MJ, Ten Have T, Katz I, Tweedy K, Battistini $M$ (2004). Lack of efficacy of estradiol for depression in postmenopausal women: a randomized, controlled trial. Biol Psychiatr 55: 406-412.

Moss RL, Gu Q (1999). Estrogen: mechanisms for a rapid action in CA1 hippocampal neurons. Steroids 64: 14-21.

Nagata H, Nozaki M, Nakano H (2005). Short-term combinational therapy of low-dose estrogen with selective serotonin re-uptake inhibitor (fluvoxamine) for oophorectomized women with hot flashes and depressive tendencies. J Obstet Gynaecol Res 31: 107-114.

Nilsen J, Chen S, Brinton RD (2002). Dual action of estrogen on glutamate-induced calcium signaling: mechanisms requiring interaction between estrogen receptors and src/mitogen activated protein kinase pathway. Brain Res 930: 216-234.

Nishizuka M, Arai Y (1982). Synapse formation in response to estrogen in the medial amygdala developing in the eye. Proc Natl Acad Sci 79: 7024-7026.

Nolen-Hoeksema S (1987). Sex differences in unipolar depression: evidence and theory. Psychol Bull 101: 259-282.

Nomikos GC, Spyraki C (1988). Influence of oestrogen on spontaneous and diazepam-induced exploration of rats in an elevated plus maze. Neuropharmacology 27: 691-696.

Okada M, Hayashi N, Kometani M, Nakao K, Inukai T (1997). Influences of ovariectomy and continuous replacement of $17 \beta$ estradiol on the tail skin temperature and behavior in the forced swimming test in rats. Jpn J Pharmacol 73: 93-96.

O'Malley BW, Means AR (1974). Female steroid hormones and target cell nuclei. Science 183: 610-620.

Osterlund MK, Hurd YL (1998). Acute $17 \beta$-estradiol treatment down-regulates serotonin 5HT1A receptor mRNA expression in the limbic system of female rats. Brain Res Mol Brain Res 55: 169-172.

Packard MG (1998). Posttraining estrogen and memory modulation. Horm Behav 34: 126-139.
Paech K, Webb P, Kuiper GG, Nilsson S, Gustafsson J, Kushner PJ et al (1997). Differential ligand activation of estrogen receptors $\mathrm{ER} \alpha$ and $\operatorname{ER} \beta$ at AP1 sites. Science 277: 1508-1510.

Palanza P (2001). Animal models of anxiety and depression: how are females different? Neurosci Biobehav Rev 25: 219-233.

Patchev VK, Hassan AH, Holsboer DF, Almeida OF (1996). The neurosteroid tetrahydroprogesterone attenuates the endocrine response to stress and exerts glucocorticoid-like effects on vasopressin gene transcription in the rat hypothalamus. Neuropsychopharmacology 15: 533-540.

Patisaul HB, Blum A, Luskin JR, Wilson ME (2005). Dietary soy supplements produce opposite effects on anxiety in intact male and female rats in the elevated plus-maze. Behav Neurosci 119: 587-594.

Paul SM (1988). Anxiety and depression: a common neurobiological substrate? J Clin Psychiatry 49(Suppl): 13-16.

Pfaff D, Keiner M (1973). Atlas of estradiol-concentrating cells in the central nervous system of the female rat. J Comp Neurol 151: 121-158.

Pfaff DW, McEwen BS (1983). Action of estrogens and progestins on nerve cells. Science 219: 808-814.

Rachman IM, Unnerstall JR, Pfaff DW, Cohen RS (1998). Estrogen alters behavior and forebrain c-fos expression in ovariectomized rats subjected to the forced swim test. Proc Natl Acad Sci 95: 13941-13946.

Rapp SR, Espeland MA, Shumaker SA, Henderson VW, Brunner RL, Manson JE et al, WHIMS Investigators (2003). Effect of estrogen plus progestin on global cognitive function in postmenopausal women: the Women's Health Initiative Memory Study: a randomized controlled trial. JAMA 289: 2663-2672.

Raps D, Barthe PL, Desaulles PA (1971). Plasma and adrenal corticosterone levels during the different phases of the sexual cycle in normal female rats. Experientia 27: 339-340.

Rasia-Filho AA, Fabian C, Rigoti KM, Achaval M (2004). Influence of sex, estrous cycle and motherhood on dendritic spine density in the rat medial amygdala revealed by the Golgi method. Neuroscience 126: 839-847.

Rausch JL, Parry BL (1993). Treatment of premenstrual mood symptoms. Psychiatr Clin North Am 16: 829-839.

Redei E, Li L, Halasz I, McGivern RF, Aird F (1994). Fast glucocorticoid feedback inhibition of ACTH secretion in the ovariectomized rat: effect of chronic estrogen and progesterone. Neuroendocrinology 60: 113-123.

Rhodes ME, Frye CA (2001). Inhibiting progesterone metabolism in the hippocampus of proestrous rats decreases anxiolytic, and enhances, exploration and analgesia. Cogn Affect Behav Neurosci 1: 287-296.

Rhodes ME, Frye CA (2004). Estrogen has mnemonic-enhancing effects in the inhibitory avoidance task. Pharmacol Biochem Behav 78: 551-558.

Roca CA, Schmidt PJ, Altemus M, Deuster P, Danaceau MA, Putnam K et al (2003). Differential menstrual cycle regulation of hypothalamic-pituitary-adrenal axis in women with premenstrual syndrome and controls. J Clin Endocrinol Metab 88: 3057-3063.

Rocha BA, Fleischer R, Schaeffer JM, Rohrer SP, Hickey GJ (2005). $17 \beta$-Estradiol-induced antidepressant-like effect in the Forced Swim Test is absent in estrogen receptor- $\beta$ knockout (BERKO) mice. Psychopharmacology 179: 637-643.

Rodriguez-Sierra JF, Howard JL, Pollard GT, Hendricks SE (1984). Effect of ovarian hormones on conflict behavior. Psychoneuroendocrinology 9: 293-300.

Romano GJ, Harlan RE, Shivers BD, Howells RD, Pfaff DW (1988). Estrogen increases proenkephalin messenger ribonucleic acid levels in the ventromedial hypothalamus of the rat. Mol Endocrinol 2: 1320-1328.

Rossouw JE, Anderson GL, Prentice RL, LaCroix AZ, Kooperberg C, Stefanick ML et al, Writing Group for the Women's Health 
Initiative Investigators (2002). Risks and benefits of estrogen plus progestin in healthy postmenopausal women: principal results From the Women's Health Initiative randomized controlled trial. JAMA 288: 321-333.

Rubinow DR, Schmidt PJ (1995). The neuroendocrinology of menstrual cycle mood disorders. Ann NY Acad Sci 771: 648-659.

Rudick CN, Woolley CS (2000). Estradiol induces a phasic Fos response in the hippocampal CA1 and CA3 regions of adult female rats. Hippocampus 10: 274-283.

Saletu B, Brandstatter N, Metka M, Stamenkovic M, Anderer P, Semlitsch HV et al (1995). Double-blind, placebo-controlled, hormonal, syndromal and EEG mapping studies with transdermal oestradiol therapy in menopausal depression. Psychopharmacology 122: 321-329.

Santoro N, Brown JR, Adel T, Skurnick JH (1996). Characterization of reproductive hormonal dynamics in the perimenopause. $J$ Clin Endocrinol Metab 81: 1495-1501.

Schmidt PJ, Haq N, Rubinow DR (2004). A longitudinal evaluation of the relationship between reproductive status and mood in perimenopausal women. Am J Psychiatr 161: 2238-2244.

Schmidt PJ, Nieman L, Danaceau MA, Tobin MB, Roca CA, Murphy JH et al (2000). Estrogen replacement in perimenopause-related depression: a preliminary report. Am J Obstet Gynecol 183: 414-420.

Schmidt PJ, Nieman LK, Danaceau MA, Adams LF, Rubinow DR (1998). Differential behavioral effects of gonadal steroids in women with and in those without premenstrual syndrome. N Engl J Med 338: 209-216.

Schmitz C, Rhodes ME, Bludau M, Kaplan S, Ong P, Ueffing I et al (2002). Depression: reduced number of granule cells in the hippocampus of female, but not male, rats due to prenatal restraint stress. Mol Psychiatr 7: 810-813.

Schneier FR, Johnson J, Hornig CD, Liebowitz MR, Weissman MM (1992). Social phobia. Comorbidity and morbidity in an epidemiologic sample. Arch Gen Psychiatr 49: 282-288.

Seeman MV (1997). Psychopathology in women and men: focus on female hormones. Am J Psychiatr 154: 1641-1647.

Sherwin BB (1991). The impact of different doses of estrogen and progestin on mood and sexual behavior in postmenopausal women. J Clin Endocrinol Metab 72: 336-343.

Sherwin BB, Gelfand MM (1985). Sex steroids and affect in the surgical menopause: a double-blind, cross-over study. Psychoneuroendocrinology 10: 325-335.

Shors TJ, Pickett J, Wood G, Paczynski M (1999). Acute stress persistently enhances estrogen levels in the female rat. Stress 3: 163-171.

Shughrue PJ, Lane MV, Merchenthaler I (1997). Comparative distribution of estrogen receptor- $\alpha$ and $-\beta$ mRNA in the rat central nervous system. J Comp Neurol 388: 507-525.

Shughrue PJ, Scrimo PJ, Merchenthaler I (1998). Evidence for the colocalization of estrogen receptor- $\beta$ mRNA and estrogen receptor- $\alpha$ immunoreactivity in neurons of the rat forebrain. Endocrinology 139: 5267-5270.

Shumaker SA, Legault C, Thal L, Wallace RB, Ockene JK, Hendrix SL et al, WHIMS Investigators (2003). Estrogen plus progestin and the incidence of dementia and mild cognitive impairment in postmenopausal women: the Women's Health Initiative Memory Study: a randomized controlled trial. JAMA 289: 2651-2662.

Sibolboro Mezzacappa E, Tu AY, Myers MM (2003). Lactation and weaning effects on physiological and behavioral response to stressors. Physiol Behav 78: 1-9.

Simpkins JW, Wang J, Wang X, Perez E, Prokai L, Dykens JA (2005). Mitochondria play a central role in estrogen-induced neuroprotection. Curr Drug Targets CNS Neurol Disord 4: 69-83.

Sinchak K, Eckersell C, Quezada V, Norell A, Micevych P (2000). Preproenkephalin mRNA levels are regulated by acute stress and estrogen stimulation. Physiol Behav 69: 425-432.
Slater J, Blizard DA (1976). A reevaluation of the relation between estrogen and emotionality in female rats. J Comp Physiol Psychol 90: 755-764.

Smith RN, Studd JW, Zamblera D, Holland EF (1995). A randomised comparison over 8 months of 100 micrograms and 200 micrograms twice weekly doses of transdermal oestradiol in the treatment of severe premenstrual syndrome. $\mathrm{Br} J$ Obstet Gynaecol 102: 475-484.

Smoller JW, Pollack MH, Wassertheil-Smoller S, Barton B, Hendrix SL, Jackson RD et al, Women's Health Initiative Investigators (2003). Prevalence and correlates of panic attacks in postmenopausal women: results from an ancillary study to the Women's Health Initiative. Arch Intern Med 163: 2041-2050.

Soares CN, Almeida OP, Joffe H, Cohen LS (2001). Efficacy of estradiol for the treatment of depressive disorders in perimenopausal women: a double-blind, randomized, placebo-controlled trial. Arch Gen Psychiatr 58: 529-534.

Sternberg WF (1999). Sex differences in the effects of prenatal stress on stress-induced analgesia. Physiol Behav 68: 63-72.

Stoffel EC, Craft RM (2004). Ovarian hormone withdrawal-induced 'depression' in female rats. Physiol Behav 83: 505-513.

Suzuki S, Handa RJ (2004). Regulation of estrogen receptor-beta expression in the female rat hypothalamus: differential effects of dexamethasone and estradiol. Endocrinology 145: 3658-3670.

Szuran TF, Pliska V, Pokorny J, Welzl H (2000). Prenatal stress in rats: effects on plasma corticosterone, hippocampal glucocorticoid receptors, and maze performance. Physiol Behav 71: 353-362.

Takahashi LK, Haglin C, Kalin NH (1992). Prenatal stress potentiates stress-induced behavior and reduces the propensity to play in juvenile rats. Physiol Behav 51: 319-323.

Tena-Sempere M, Navarro VM, Mayen A, Bellido C, SanchezCriado JE (2004). Regulation of estrogen receptor (ER) isoform messenger RNA expression by different ER ligands in female rat pituitary. Biol Reprod 70: 671-678.

Toran-Allerand CD, Guan X, MacLusky NJ, Horvath TL, Diano S, Singh $M$ et al (2002). ER-X: a novel, plasma membraneassociated, putative estrogen receptor that is regulated during development and after ischemic brain injury. $J$ Neurosci 22: 8391-8401.

Tremblay GB, Tremblay A, Copeland NG, Gilbert DJ, Jenkins NA, Labrie F et al (1997). Cloning, chromosomal localization, and functional analysis of the murine estrogen receptor beta. Mol Endocrinol 11: 353-365.

Vasudevan N, Kow LM, Pfaff DW (2001). Early membrane estrogenic effects required for full expression of slower genomic actions in a nerve cell line. Proc Natl Acad Sci 98: 12267-12271.

Viau V, Meaney MJ (1991). Variations in the hypothalamicpituitary-adrenal response to stress during the estrous cycle in the rat. Endocrinology 129: 2503-2511.

Vongher JM, Frye CA (1999). Progesterone in conjunction with estradiol has neuroprotective effects in an animal model of neurodegeneration. Pharm Biochem Behav 64: 777-785.

Wade CB, Robinson S, Shapiro RA, Dorsa DM (2001). Estrogen receptor (ER) $\alpha$ and $\operatorname{ER} \beta$ exhibit unique pharmacologic properties when coupled to activation of the mitogen-activated protein kinase pathway. Endocrinology 142: 2336-2342.

Walf AA, Frye CA (2003). Anti-nociception following exposure to trimethylthiazoline, peripheral or intra-amygdala estrogen and/ or progesterone. Behav Brain Res 144: 77-85.

Walf AA, Frye CA (2005a). Estradiol's effects to reduce anxiety and depressive behavior may be mediated by estradiol dose and restraint stress. Neuropsychopharmacology 30: 1288-1301.

Walf AA, Frye CA (2005b). ER $\beta$-selective estrogen receptor modulators produce antianxiety behavior when administered systemically to ovariectomized rats. Neuropsychopharmacology 30: 1598-1609. 
Walf AA, Jeddi S, Frye CA (2003). Estradiol has Anxiolytic and Cognitive Enhancing Effects in Prenatally Stressed and Nonstressed Female Rats. American Neuroendocrine Society Workshop on the Neuroendocrinology of Development: Philadelphia, PA.

Walf AA, Rhodes ME, Frye CA (2004). Anti-depressant effects of $\mathrm{ER} \beta$ selective estrogen receptor modulators in the forced swim test. Pharm Biochem Behav 78: 523-529.

Walf AA, Sumida K, Frye CA (2005). Inhibiting $5 \alpha$-reductase in the amygdala attenuates anti-anxiety and anti-depressive behavior of naturally-receptive and hormone-primed ovariectomized rats. Psychopharmacology (in press).

Walker DL, Toufexis DJ, Davis M (2003). Role of the bed nucleus of the stria terminalis versus the amygdala in fear, stress, and anxiety. Eur J Pharmacol 463: 199-216.

Warnock JK, Bundren JC, Morris DW (2000). Depressive mood symptoms associated with ovarian suppression. Fertil Steril 74: 984-986.

Wartella J, Amory E, Lomas LM, Macbeth A, McNamara I, Stevens $\mathrm{L}$ et al (2003). Single or multiple reproductive experiences attenuate neurobehavioral stress and fear responses in the female rat. Physiol Behav 79: 373-381.

Watanabe $\mathrm{T}$, Inoue $\mathrm{S}$, Ogawa $\mathrm{S}$, Ishii $\mathrm{Y}$, Hiroi $\mathrm{H}$, Ikeda $\mathrm{K}$ et al (1997). Agonistic effect of tamoxifen is dependent on cell type, ERE-promoter context, and estrogen receptor subtype: functional difference between estrogen receptors $\alpha$ and $\beta$. Biochem Biophys Res Commun 236: 140-145.

Watters JJ, Campbell JS, Cunningham MJ, Krebs EG, Dorsa DM (1997). Rapid membrane effects of steroids in neuroblastoma cells: effects of estrogen on mitogen activated protein kinase signalling cascade and c-fos immediate early gene transcription. Endocrinology 138: 4030-4033.

Weinstock M (1997). Does prenatal stress impair coping and regulation of hypothalamic-pituitary-adrenal axis? Neurosci Biobehav Rev 21: 1-10.

Weinstock M (2001). Alterations induced by gestational stress in brain morphology and behaviour of the offspring. Prog Neurobiol 65: 427-451.

Weinstock M, Matlina E, Maor GI, Rosen H, McEwen BS (1992). Prenatal stress selectively alters the reactivity of the hypo- thalamic-pituitary adrenal system in the female rat. Brain Res 595: 195-200.

Weissman MM, Klerman GL (1977). Sex differences and the epidemiology of depression. Arch Gen Psychiatr 34: 98-111.

Weissman MM, Olfson M (1995). Depression in women: implications for health care research. Science 269: 799-801.

Wise PM (2003). Estrogens: protective or risk factors in brain function? Prog Neurobiol 69: 181-191.

Wittchen HU, Hoyer J (2001). Generalized anxiety disorder: nature and course. J Clin Psychiatr 62: 15-19.

Woolley CS, Gould E, Frankfurt M, McEwen BS (1990). Naturally occurring fluctuation in dendritic spine density on adult hippocampal pyramidal neurons. J Neurosci 10: 4035-4039.

Woolley CS, McEwen BS (1993). Roles of estradiol and progesterone in regulation of hippocampal dendritic spine density during the estrous cycle in the rat. J Comp Neurol 336: 293-306.

Yang SH, Liu R, Perez EJ, Wen Y, Stevens Jr SM, Valencia T et al (2004). Mitochondrial localization of estrogen receptor $\beta$. Proc Natl Acad Sci 101: 4130-4135.

Young EA (1998). Sex differences and the HPA axis: implications for psychiatric disease. J Gend Specif Med 1: 21-27.

Young EA, Altemus M, Parkison V, Shastry S (2001). Effects of estrogen antagonists and agonists on the ACTH response to restraint stress in female rats. Neuropsychopharmacology 25: 881-891.

Young EA, Korszun A (2002). The hypothalamic-pituitarygonadal axis in mood disorders. Endocrinol Metab Clin North Am 31: 63-78.

Young EA, Midgley AR, Carlson NE, Brown MB (2000). Alteration in the hypothalamic-pituitary-ovarian axis in depressed women. Arch Gen Psychiatr 57: 1157-1162.

Zimmerberg B, Farley MJ (1993). Sex differences in anxiety behavior in rats: role of gonadal hormones. Physiol Behav 54: 1119-1124.

Zuluaga MJ, Agrati D, Pereira M, Uriarte N, Fernandez-Guasti A, Ferreira A (2005). Experimental anxiety in the black and white model in cycling, pregnant and lactating rats. Physiol Behav 84: 279-286. 